\title{
DENSITY AND POROSITY OF OIL RESERVOIRS AND OVERLYING FORMATIONS FROM BOREHOLE GRAVITY MEASUREMENTS, GEBO OIL FIELD, HOT SPRINGS COUNTY, WYOMING
}

\author{
By
}

\author{
L.A. Beyer and F.G. Clutsom
}

\begin{abstract}
High-precision measurements of relative gravity were made at 75 locations over a temporarily shut-in $5,083-$ foot cased producing oil well in the Gebo oil field in the southern Big Horn Basin, Wyoming. Gravity and depth differences between adjacent stations were used to calculate the fluid-saturated bulk density of the horizontal layers of rock bracketed by each pair of measurements that extend tens to hundreds of feet outward from the well. Interval bulk density was converted to interval total porosity by assuming values for the densities of pore fluids and mineral grains.

The Gebo well penetrates sandstone, shale, carbonate, and evaporite units that range in age from Pennsylvanian to Late Cretaceous. Oil production comes from carbonate (Park City Formation) and sandstone (Tensleep Sandstone) reservoirs. Bulk density ranges from $2.33 \mathrm{~g} / \mathrm{cm}^{3}$ in a Cretaceous sandstone unit to $2.80 \mathrm{~g} / \mathrm{cm}^{3}$ in a Permian anhydritic dolomite and averages $2.55 \mathrm{~g} / \mathrm{cm}^{3}$ for the entire section. Porosity reaches 15-21 percent in sandstone units in the Frontier Formation, Cloverly Formation, Crow Mountain Sandstone, and Tensleep Sandstone. Several dolomite units in the Park City Formation have porosities as high as 14 to 18 percent.

Judging from maximum observed porosities of sandstone and shale units, the Cretaceous section appears to be overcompacted-an observation that supports independent evidence that thousands of feet of overburden has been removed from the section at Gebo by late Cenozoic erosion. Fluctuations of density and porosity are related to lithology and known variations in the abundance of bentonite, carbonate minerals, and anhydrite. For example, Cretaceous formations with abundant bentonite are less dense and more porous than Cretaceous formations without bentonite. A conspicuous and abrupt change in density and porosity near the top of the Frontier Formation appears to be due to lithologic and mineralogic variations related to a change in the environment of deposition of the rocks. Large fluctuations of intergranular porosity in the Tensleep Sandstone due to variations in cementation and abundance of dolomite completely mask the very small, possibly negligible contribution of fracture porosity.

Qualita tive comparison of the gravimetric density and porosity profiles of this study with conventional density and porosity well logs primarily illustrates the difference
\end{abstract}

in the lateral radius of investigation between these conventional types of logs and the borehole gravity method.

\section{Introduction}

This report presents formation density and porosity profiles calculated from a borehole gravity sur'ey made by the U.S. Geological Survey in the Gebo oil field in north-central Wyoming.

Borehole gravity surveys are used primarily to determine, with high relative accuracy, the in-situ density of large volumes of rock that extend tens to hundreds of feet outward from the drill hole. The objective of the borehole gravity survey in the Gebo oil field was to determine the density and porosity of formations and subformational units with special emphasis on the Frontier Formation, Park City Formation 1 , ard Tensleep Sandstone. In some cases, borehole gravity surveys can be analyzed to determine the gravitational effects of rock density anomalies associated with nearby geologic structure that is not penetrated by the drill hole.

Remote sensing of geologic structure was not an objective of the Gebo survey.

The borehole gravity method is unique for several important reasons. (1) Unlike other well-loggir q techniques, borehole gravity measurements depend directly on rock bulk density. (2) The large radius (and volume) of investigation ensures that the measurements. for all practical purposes, are unaffected by borehole fluids, borehole rugosity, casing, cement, or the region close to the borehole that may be modified by flushing or invasion by drilling fluids. (3) The method is sensitive to very small variations of formation density (usually 0.005 to $0.04 \mathrm{~g} / \mathrm{cm}^{3}$ depending on length of the borehole interval).

Proven and potential applications of borehol : gravity surveys are many: Detection of irregularly distributed porosity, detection of gas and oil zones behinc' casing, evaluation and recalibration of conventional ty'pes of well logs, vertical density profiling for gravity map interpretation and for seismic modeling and an alysis, remote detection of geological structures such as salt domes and ore bodies, large-volume determination of reservoir porosity for reserve estimates, monitoring of reservoir fluid conditions (for example, detection of gas cap coning or water invasion), and porosity evaluation of unconsolidated materials for ground water and engineer-

1 Park City Formation is accepted usage by the U.S. Geological Survey for this mostly carbonate unit of Late Permian age, although the name Phosphoria Formation is in common use by many. The U.S. Geological Survey applies the name Phosphoria Formation to equivalent marine shale, phosphorite, and chert found west of the Big Horn Basin (Horn, 1963; Maughan, 1975). 
ing studies.

The usefulness of borehole gravity measurements for any application depends very strongly on the type and quality of independent drill hole, geological, and geophysical data that are available for analysis. For example, density profiles calculated for borehole gravity measurements are easily converted to porosity profiles provided reasonable assumptions can be made about the pore fluid density and grain density of the rocks. (See the explanations for columns 15 through 18, Supplement.) Relatively small gravity variations due to remote geologic structure may be hidden in the larger gravity variations due to rock density fluctuations immediately around the borehole. In this case, an independent method is needed to estimate the densities of the rocks immediately around the borehole (well logs, core analyses, geological factors).

Selected readings on the borehole gravity method include Smith (1950), McCulloh (1966), McCulloh and others (1968), Beyer (1971), Rasmussen (1973), Jageler (1976), and Bradley (1976).

Acknowledgments. - The permission of Continental Oil Company to log the Gebo Unit No. 28 and the cooperation and help of W. C. Blackburn, H. J. King, M. Miller, D. W. Mitchell, R. McKnire, and G. Vaughn of Continental's production staff in Casper and Thermopolis, Wyo., are gratefully acknowledged. The content of this report is the responsibility of the senior author and does not necessarily reflect the opinions of the owners or operator of the well. The junior author was responsible for the maintenance and operation of the borehole gravimeter during the survey. A successful borehole gravity survey is always a team effort, and I am pleased to acknowledge and thank the other members of the field party: C. D. Cavit, N. M. Morgan, K. A. Pisciotto, and N. B. Sasnett. Their unfailing effort and the cooperation of Continental Oil Company made the survey and this report possible.

\section{Geologic setting}

The Gebo oil field is located approximately 8 miles north of the town of Thermopolis in the southern Big Horn Basin in central Wyoming (fig. 1). The productive area is approximately 1.5 square miles in gentle hills in secs. $14,15,22,23$, and 24, T. 44 N., R. 95 W. The Gebo anticline is one of several oil-producing northwestsoutheast-trending anticlines that have steeper dips facing south toward the Owl Creek Mountains (Zapp, 1956; fig. 2). Drilling indicates that the flanks of the Gebo anticline steepen and the fold axis shifts northeastward with increasing depth. Sedimentary units involved in the fold were deposited in a cratonic setting and range in age from Cretaceous to Cambrian. Major unconformities are located throughout this sequence (sheet 1 ). Mapped surface closure is about 500 feet and proven closure on the Park City Formation is about 700 feet according to Mees and Bowers (1952). These authors state that several minor transverse normal faults cut the fold at the surface and a longitudinal normal fault, with a displacement of 175 feet, cuts the Frontier Formation on the north flank. A regional geologic map that includes the Gebo oil field is given by Weitz and Love (1952).

\section{Petroleum development and production}

The Gebo structure was recognized long before commercial quantities of oil and gas were discovered. Between 1916 and 1931, two wells were drilled to the Frontier Formation and one to the Morrison Formation. One well drilled in 1926 "found 3 million cubic feet of sweet gas in the Muddy sandstone" (Mees and Bowers, 1952 , p. 113). Commercial production was discovered in 1943 by the Continental Oil Company Gebo Unit No. 1 that was drilled to the Tensleep Sandstone but was plugged back to the Park City Formation. In 1951 commercial production in the Tensleep Sandstone was established with the completion of the Gebo Unit No. 32. The Gebo Unit No. 26 tested the Curtis sandstone 2 and encountered oil believed to have a common origin with the deeper hydrocarbon accumulations (Stone, 1967, p. 2105). Only the Gebo Unit No. 32 produces from the Curtis sandstone.

The Gebo oil field has been under primary production since its discovery in 1943. The Park City and Tensleep reservoirs are not in communication, but each has a very active water drive from the northeast and a partial water drive from the southwest. A natural decline in production of about 7 percent in the late 1960's and early 1970's was reversed in 1972 by an infill drilling program designed to reach undrained parts of the reservoirs. This was supplemented, beginning in 1976, with a hydraulic fracture-stimulation program in the Tensleep reservoir. Both of these programs have kept production well above the 1970 level. Cumulative production of oil and gas from the Gebo oil field is given in table 1.

\section{Reservoir and hydrocarbon characteristics}

Cupps and Fry (1967) report that Park City and Tensleep oils collected in 1944 had API gravities of $29^{\circ}$ and $24^{\circ}$ respectively, were undersaturated with gas (gas-oil ratios less than 50 cubic feet per barrel), and had similar compositions. Present-day Tensleep reservoir and hyrocarbon characteristics are given in table 2 . From these data the in-situ densities of the Tensleep reservoir oil and water are calculated to be about $0.89 \mathrm{~g} / \mathrm{cm}^{3}$ and about $1.005 \mathrm{~g} / \mathrm{cm}^{3}$ respectively. The average density of reservoir pore fluids is $0.93 \mathrm{~g} / \mathrm{cm}^{3}$ if reservoir water saturation is 35 percent. Using this estimate of reservoir water saturation, an average grain density of $2.65 \mathrm{~g} / \mathrm{cm}^{3}$, and a porosity of 15 percent, the oil reservoir rock is only about $0.01 \mathrm{~g} / \mathrm{cm}^{3}$ less dense than equivalent rock that is 100 percent saturated with formation water. Density contrasts are even smaller between hydrocarbonbearing rock and equivalent water-saturated rocks for reservoir porosities less than 15 percent.

2 The Curtis sandstone is a driller's name for an oil producing zone in the Crow Mountain Sandstone of Late Triassic age in several fields along the southwest flank of the Big Horn Basin. 


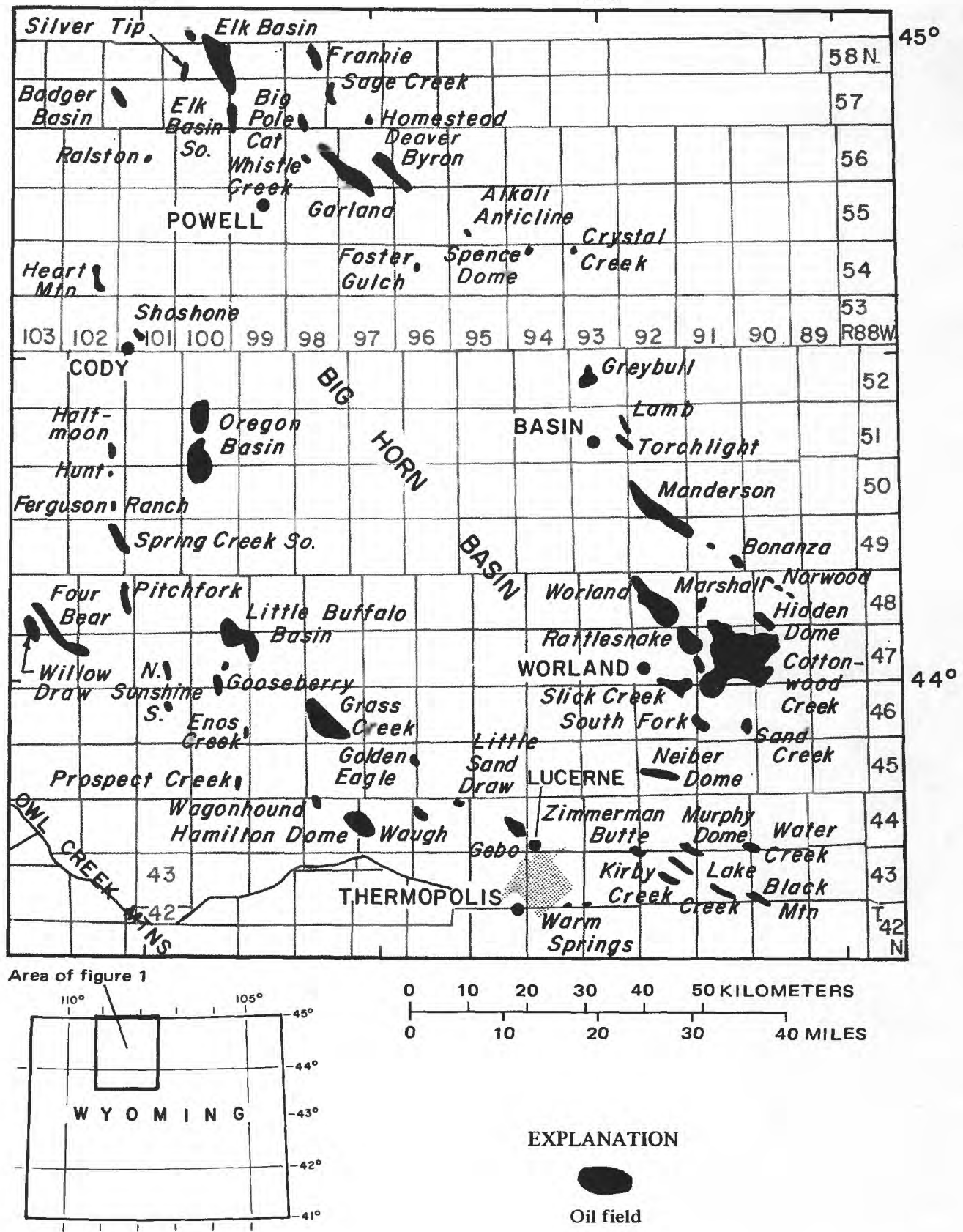

Figure 1.-Index map of Big Horn Basin area,Wyoming, showing location of Gebo oil field. 
Table 1.-Total oil, gas, and water production from the Gebo oil field through July 1977

\begin{tabular}{lcc}
\hline & $\begin{array}{c}\text { Producing } \\
\text { wells } 7 / 77\end{array}$ & $\begin{array}{c}\text { Cumulative production } \\
\text { (Oil and water in bbls., gas in mcf.) }\end{array}$ \\
\hline Curtis Sandstone $^{1}$ & 1 & $\begin{array}{c}4,996 \text { oil } \\
0 \text { gas }\end{array}$ \\
Park City Formation & 23 & $1,090,371$ water \\
& & $15,431,425$ oil \\
Tensleep Sandstone & 25 & 660,000 gas (approx.) \\
& $92,601,041$ water \\
& & $7,736,268$ oil \\
70,000 gas (approx.) \\
\hline
\end{tabular}

${ }^{1}$ Local name for oil-producing unit in Crow Mountain Sandstone.

Table 2.-Selected data for the Tensleep reservoir of the Gebo oil field

\begin{tabular}{lc}
\hline Depth & $4830-5300$ feet \\
Temperature & $135^{\circ} \mathrm{F}\left(57.2^{\circ} \mathrm{C}\right)$ \\
Pressure (average) & $2300 \mathrm{psia}$ \\
Water saturation (average) & 35 percent \\
Salinity of water (Briggs and Espach, & 9923 ppm (calculated total solids) \\
$\quad 1960$, p. 294) & $25.5^{\circ}$ \\
API gravity of oil & $30-40$ \\
Gas-oil ratio & 1.01 (approx.) \\
Formation volume & $<1$ to 16 percent \\
Range of effective porosity of cores from & \\
\hline Gebo Unit Nos. 5 and 52 & \\
\hline
\end{tabular}

The above calculations assume that the hydrocarbonand water-saturated rocks have the same porosity. The small density contrasts suggest that borehole gravity measurements cannot detect the oil-bearing intervals in the Tensleep reservoir at Gebo solely because of the density contrast between the oil reservoir fluids and the formation water. If, on the other hand, the oil-bearing rocks are selectively more porous than the watersaturated rocks, the density contrast between the oilbearing reservoir rocks and associated water-bearing rocks will be greater and possibly detectable with borehole gravity density logging. In this case, relatively high porosity and relatively low pore-fluid density both contribute to lower the bulk density of the interval. Further information on the early development and reservoir characteristics of the Gebo field can be found in Mees and Bowers (1952), Wyoming Geological Association (1957), and Biggs and Espach (1960).

Well history and gravity logging program

Borehole gravity measurements were made in the Gebo Unit No. 28, which is located at a ground elevation of 4,463 feet in sec. 23, T. 44 N., R. 95 W. (fig. 2). This well was drilled in 1948 to a total depth of 6,608 feet and bottomed in the Gallatin Formation (Upper Cam- brian). After drill-stem tests of the Madison Limestone, Amsden Formation, and Tensleep Sandstone, this well was plugged back to produce, with occasional acid treatment, until 1958 from the interval 4,558-4,598 feet in the upper part of the Park City Formation. In 1958 the interval 4,614-4,630 feet was perforated, acidized, and produced together with the shallower zone. In 1974 the intervals $4,836-4,860,4,882-4,902,4,984-5,022$, and $5,056-5,062$ feet in the Tensleep Sandstone were perforated, acidized, and produced. Between 1948 and 1974 the Gebo Unit No. 28 produced 606,221 barrels of oil and 7,072,343 barrels of water from the Park City Formation. Production from the Tensleep Sandstone from July 1974 through July 1977 was 22,946 barrels of oil and 57,806 barrels of water.

The Gebo Unit No. 28 was selected for the survey because it is located at a structurally high position where the dip is relatively low and sufficiently large casing to accommodate the gravity logging tool is set through most of the Tensleep Sandstone reservoir. A suite of modern logs is not available from this well, but conventional cores were cut and analyzed. Modern logs and core analyses are available from nearby wells.

Borehole gravity stations were selected at or near formation boundaries and to bracket discrete subfor- 


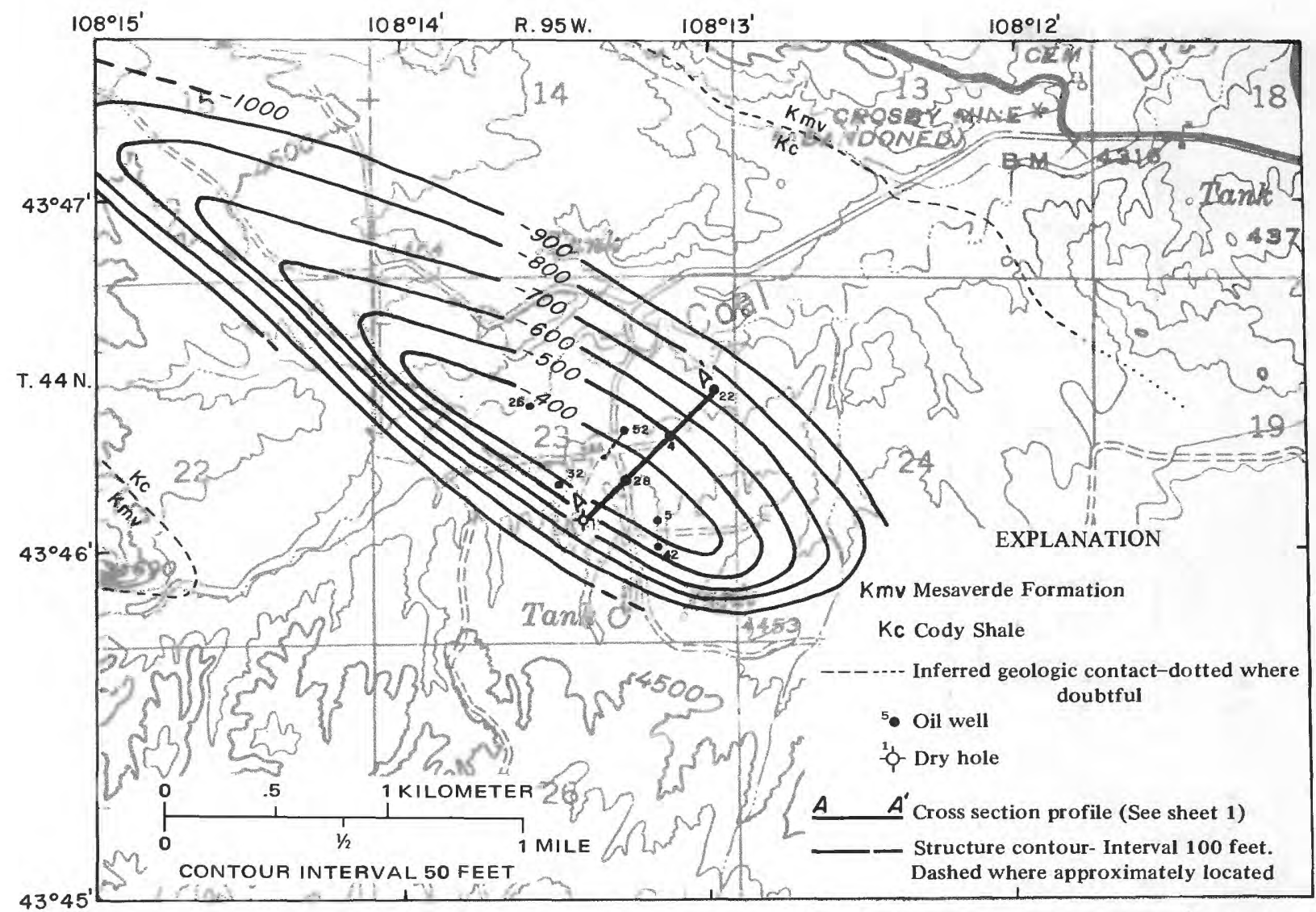

Figure 2.-Structure contour map of Gebo oil field showing location of structure cross section $A-A^{\prime}$ and selected wells. Structure contours on top of Tensleep Sandstone used by permission of Continental Oil Company. Base from U.S. Geological Survey topographic series edition sheet, 1:62 500; Kirby, 1945.

mational intervals identified from the electric $\log$ as being lithologically distinctive or containing distinctive pore-fluids. This procedure was used to examine various sandstone intervals in the Frontier Formation, Muddy Sandstone Member of the Thermopolis Shale, Pryor Conglomerate Member of the Cloverly Formation, Curtis sandstone of the Crow Mountain Sandstone, and a number of selected intervals in the Park City Formation and Tensleep Sandstone. Parts of the section that are believed to be relatively homogeneous lithologically over large intervals or to have low potential for producible oil or gas were not logged in detail (for example, the Cody and Mowry Shales, the Shell Creek Member (Curry, 1962) of the Thermopolis Shale and the Sundance and Red Peak Formations).

An operational summary of the borehole gravity survey in the Gebo Unit No. 28 is given in table 3.

\section{Results of borehole gravity survey}

A tabulation of the data for the borehole gravity survey with explanation is given in the supplement. Detailed profiles of interval density and porosity ${ }^{3}$ calculated from the borehole gravity survey are given on sheet
2 with the electric log from the Gebo Unit No. 28. Profiles of interval density and porosity are generalized by formation in figure 3 . The detailed density and porosity profiles are plotted on the gamma-gamma density and neutron porosity logs from the nearby Gebo Unit No. 52 and on the cased-hole neutron porosity log from the Gebo Unit No. 28 on sheet 3. Effective porosities of conventional core samples taken from the Gebo Unit Nos. 28 and 52 also are plotted on sheet 3. Each interval is labeled with its interval number for reference purposes (column 19 of data tabulation, Supplement). Error bars that represent estimated standard deviation accompany most intervals (columns 14 and 18 of data tabulation, Supplement). The discussion that follows utilizes well logs from the Gebo Unit Nos. 28 and 52 and other wells, descriptions of well cuttings from the nearby Gebo Unit No. 42, and previous investigations.

\section{Cody Shale (Upper Cretaceous)}

The Cody Shale (intervals 1 and 2 ) is composed of marine shale, siltstone, and sandstone (Keefer, 1972). Shale predominates in the lower part of the formation, which locally intertongues with the upper part of the

3 Interval density is the gravitational average density of the stratified or massive rocks bracketed by the pair borehole gravity measurements. In practice the investigated region extends outward from the borehole for a distance equal to 5 to 10 times the vertical distance between the gravity measurements. Interval porosity is calculated from interval density (see explanation to columns 17 and 18, Supplement) 

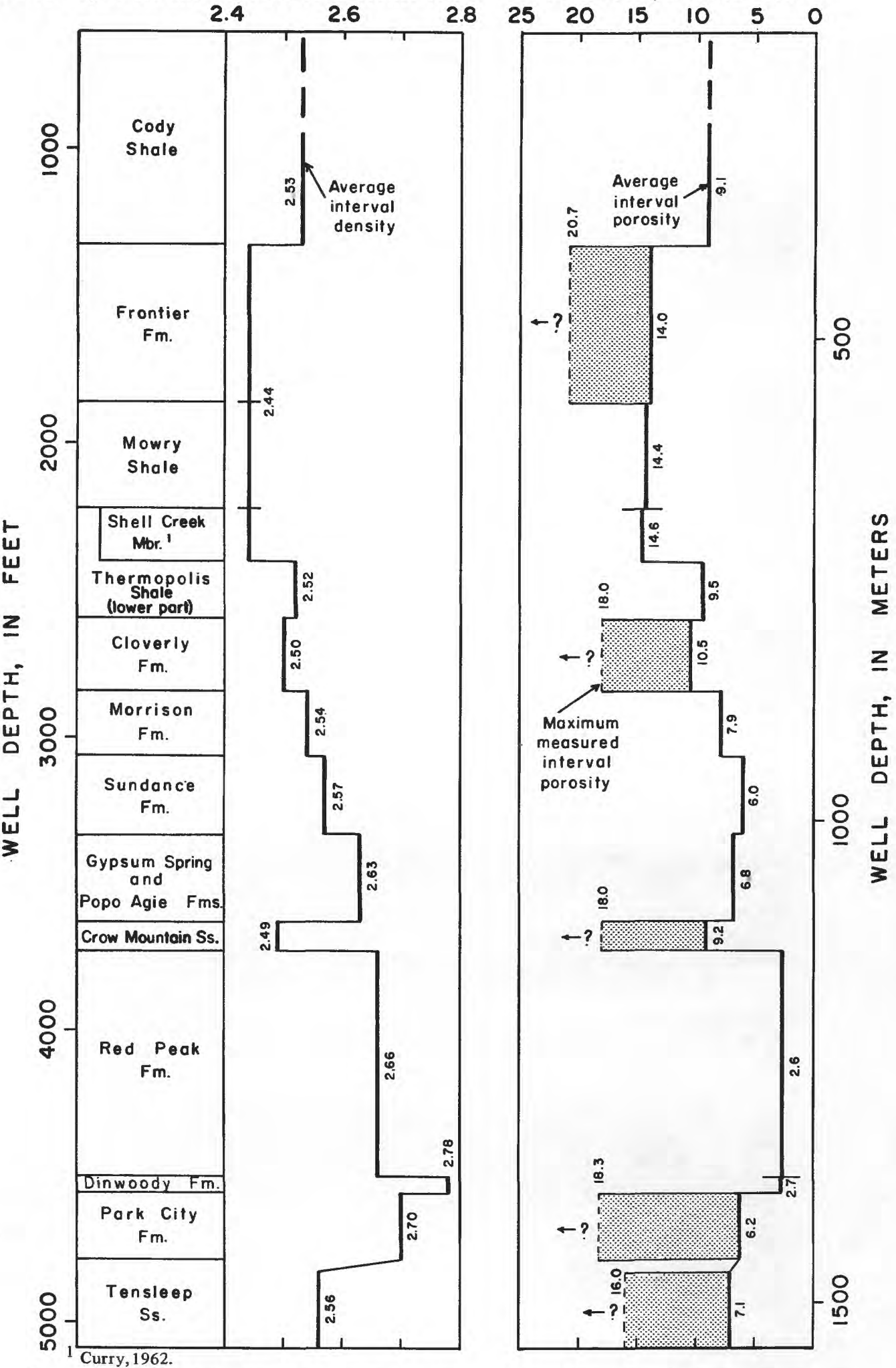

Figure 3.-Interval density and porosity profiles calculated from borehole gravity measurements in Gebo Unit No. 28. Profile values are averaged by formation. Range of average to maximum interval porosity is shown for five formations logged in detail. 1 Curry, 1962. 
Table 3.-Operation summary of borehole gravity survey in Gebo Unit No. 28

\begin{tabular}{lr}
\hline Time and date & 0310 GMT \\
Lapse time from first to last & 14 hours \\
gravity reading & 5083 feet \\
Logged depth & 75 \\
Number of borehole gravity stations & 86 \\
Number of borehole gravity readings & 8 \\
Number of downhole gravity bases & 74 \\
Number of intervals & 713.8 feet \\
Largest interval & 6.2 feet \\
Smallest interval & 57 percent \\
Percent of time spent at gravity stations & 43 percent \\
Percent of time spent moving logging tool & \\
Average station time spent leveling and & 5.5 minutes \\
reading gravimeter &
\end{tabular}

Frontier Formation. Well cuttings indicate that the Cody Shale is partly calcareous and partly glauconitic and contains siderite nodules. The interval density and porosity of the Cody Shale average $2.53 \mathrm{~g} / \mathrm{cm}^{3}$ and 9 percent respectively (fig. 3 ).

\section{Frontier Formation (Upper Cretaceous)}

The Frontier Formation (intervals 3 through 21) is a sequence of alternating sandstone and shale with minor amounts of conglomerate, bentonite, and carbonaceous shale or coal (Cobban and Reeside, 1952; Goodell, 1962; Keefer, 1972). According to Siemers (1975, p. 86) the Frontier Formation in the Bighorn Basin generally grades "from marine deposits at the base to paludal and fluvial in the middle of the formation (especially to the west) to a return to marine at the top." Regional correlation of individual units for distances of more than several miles is difficult in most cases because of facies changes and the lenticularity of individual beds. Reliable correlations are possible with the use of time-equivalent bentonite beds and some persistent stratigraphic intervals, both of which frequently can be identified on well logs (Hunter, 1952; Goodell, 1962; Van Houten, 1962). Diagnostic marine invertebrate fossils in the upper part of the formation and comparisons of paleoenvironments are also useful for correlation purposes (Merewether and others, 1975; Siemers, 1975).

Hunter (1952) and E. A. Merewether (written commun., 1977) have measured and described outcrops of the Frontier Formation exposed about 6 miles southeast of the Gebo oil field in sec. 9, T. 43 N., R. 94 W., near the town of Thermopolis. This surface section is correlated with the Frontier section in the Gebo Unit No. 1 by Hunter (1952, plate 3) and with two subsurface sections near the Gebo oil field by Merewether and others (1975, fig. 7, sections 15,16 and L). The Gebo Unit No. 28 is about halfway between and in line with subsurface sections 15 and 16 of Merewether, Cobban, and Ryder (1975). Well logs and descriptions of well cuttings from the Gebo oil field show that most individual units in the Frontier Formation can be cor- related from well to well over the oil field, and some could be correlative with the exposures studied by Hunter and Merewether.

Intervals 3 through 7 near the top of the Frortier Formation and interval 12 are the least porous units in the formation and are less porous than many sandstone units in older underlying formations (sheet 2). Intervals 3 through 7 correspond to about 70 feet of fine- to coarse-grained, poorly sorted, partly conglomeratic sandstone with a few interbeds of siltstone and shale. Sandstone units are glauconitic and calcareous and locally contain inclusions of shale. Conglomerate units contain chert pebbles. Interval 12 may correlate with a partly calcareous ridge-forming unit in the outc-op near Thermopolis. The average density and porosity of these intervals are $2.60 \mathrm{~g} / \mathrm{cm}^{3}$ and 5 percent respectively.

Intervals 9,10 , the upper part of interval 11 , and intervals 19 and 20, of the Peay Sandstone Member, bracket moderately high porosity sandstones that appear to be relatively well sorted and soft. ${ }^{4}$ Intervals $9,10,19$, and 20 have an average density of $2.39 \mathrm{~g} / \mathrm{cm}^{3}$ and, based on water saturation, an average porosity of 17 rercent.

Well logs suggest that the sandstone bracketec by interval 14 is soft and relatively well sorted (sheet 3 ). The very low density of this interval is caused b" high porosity, presence of low-density pore fluids, presence of abundant carbonaceous matter, or a combination of these. The porosities of this sandstone and the upper part of the Peay Sandstone Member (interval 1S) are shown as a function of assumed pore-fluid dens ty in figure 4.

The lower part of interval 11 and intervals $13,15,16$, 17,18 , and 21 correspond to sequences of interbedded poorly sorted siltstone, sandstone, and silty shale that generally are partly carbonaceous in the upper part, bentonitic throughout, and calcareous in the lower part of the formation. The average density and poro ity of these intervals are $2.44 \mathrm{~g} / \mathrm{cm}^{3}$ and 14 percent respectively.

4 The Peay Sandstone Member is a persistent unit throughout much of the Big Horn Basin and produces oil in some areas. 


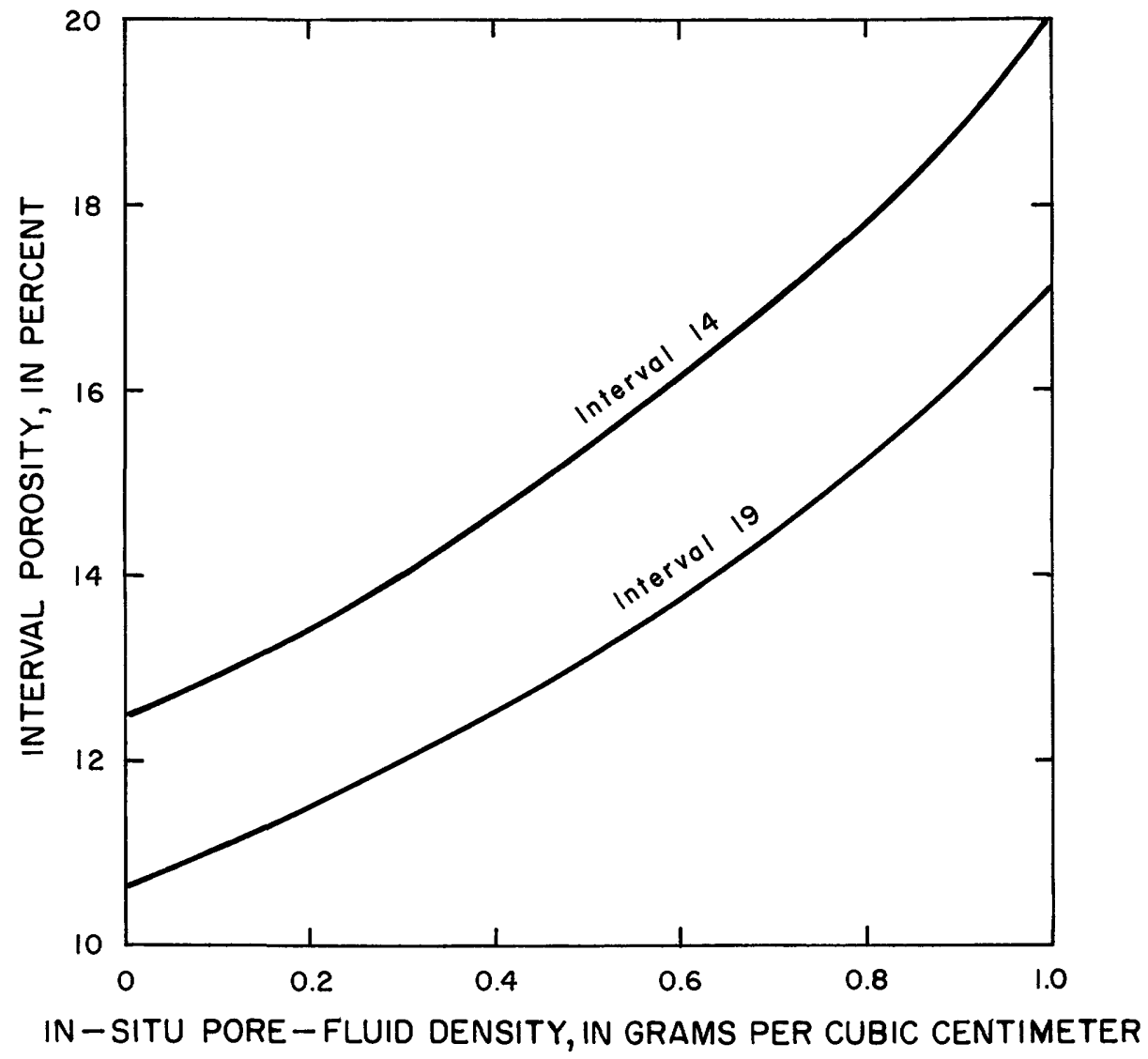

Figure 4.-Porosity versus pore fluid density for two sandstone intervals in the Frontier Formation. Curre for interval 14 shows that porosity may be as low as 12.5 percent if contained pore fluid is dry gas or as high as 20 percent if the contained pore fluid is water or oil of density $1.00 \mathrm{~g} / \mathrm{cm}^{3}$. Interval 14 curve is determined from equation

$$
\bar{\phi}=100(2.325-2.67) /\left(\bar{\rho}_{\mathrm{f}}-2.67\right)
$$

where $\bar{\phi}$ is interval porosity in percent, $2.325 \mathrm{~g} / \mathrm{cm}^{3}$ is interval density determined from borehole gravity survey, $2.67 \mathrm{~g} / \mathrm{cm}^{3}$ is assumed interval grain density, and $\bar{\rho}_{\mathrm{f}}$ is interval pore-fluid density in $\mathrm{g} / \mathrm{cm}^{3}$.

Mowry Shale and Shell Creek Member of the Thermopolis Shale (Lower Cretaceous)

The Mowry Shale (interval 22) is composed primarily of siliceous shale with abundant interbeds of bentonite, and the Shell Creek Member of the Thermopolis Shale (interval 23) is mostly nonsiliceous shale with interbeds of bentonite (Mills, 1956). The top of the Shell Creek usually is picked on electric logs at the base of the more resistive Mowry Shale. Thin interbeds of siltstone or fine-grained sandstone are locally present in these formations, especially near the base of the Shell Creek Member. The interval density and porosity of each of these units are nearly identical and are virtually the same as the average density and porosity of the overlying Frontier Formation ( fig. 3).

Muddy Sandstone Member of the Thermopolis Shale (Lower Cretaceous)

Paull (1962, fig. 9) believed the Muddy Sandstone Member of the Thermopolis Shale (intervals 24 and 25) in the area of the Gebo oil field was deposited in a deltaic and (or) littoral environment. He characterized the Muddy Sandstone Member in this area as thin- to thick-bedded, well-sorted to silty, partly crossbedded, mostly fine-grained sandstone with interbedded units of siltstone and shale. Well cuttings consist of silty finegrained sandstone with a few shale and carbonaceous inclusions. The gamma-ray log from the Gebo Unit No. 52 suggests that the Muddy consists of an upper unit of relatively well sorted sandstone about 12 feet. thick, a middle unit of shale about 1 to 2 feet thick and a lower unit of silty sandstone about 18 feet thick with thin interbeds of shale (sheet 3). The Muddy has an average interval density and porosity of $2.52 \mathrm{~g} / \mathrm{cm}^{3}$ and 8 percent in the Gebo Unit No. 28. Even though these values are averages of both higher and lower porosity units in the Muddy, it is clear that the Muddy Sandstone Member has lower porosity than many other sardstone units in the section.

Thermopolis Shale and Cloverly Formation (Lower Cretaceous)

The lower part of the Thermopolis Shale (interval 26) beneath the Muddy Sandstone Member is composed of claystone with interbeds of siltstone and very fine grained sandstone near the base (Mills, 1956; Mrughan, 1972). The upper part of the Cloverly Formation (interval 27) is composed of interbedded sandstone, s:ltstone, and mudstone. These two intervals have an average density and porosity of $2.53 \mathrm{~g} / \mathrm{cm}^{3}$ and 9 percent, which 
are very close to the density and porosity of the Cody Shale (fig. 3 and sheet 2).

The upper shale unit (Fuson shale equivalent) of the Cloverly Formation (interval 28) is described as mudstone or shale with a few thin interbeds of siltstone or sandstone (Mills, 1956; Maughan, 1972). The density and porosity of this interval are $2.44 \mathrm{~g} / \mathrm{cm}^{3}$ and 14 percent, which are very close to the density and porosity of the fine-grained rocks in the Frontier Formation, Mowry Shale, and Shell Creek Member of the Thermopolis Shale (compare with intervals 13, 15 through $18,21,22$, and 23 , sheet 2 ).

The basal unit of the Cloverly Formation, the Pryor Conglomerate Member (intervals 29 through 31), is described by Maughan (1972) as a "white quartz and black-chert-pebble conglomerate in quartzitic sandstone" in the region south of Thermopolis. Well cuttings confirm this description. Mills (1956, p. 17-18) states that "the Pryor-Lakota interval consists of conglomerates, sandstones, conglomeratic sandstones, siltstones, and thin interbeds or inclusions of varicolored shale" with minor quantities of lignitic shale and coaly material. The average density and porosity of intervals 29 through 31 and interval 33 in the upper part of the underlying Morrison Formation are $2.41 \mathrm{~g} / \mathrm{cm}^{3}$ and 15 percent, which are very close to the density and porosity of some sandstones in the Frontier Formation (compare with intervals $9,10,19$, and 20 , sheet 2). Well cuttings that correspond to interval 33 in the upper part of the Morrison Formation are fine- to medium-grained sandstone.

\section{Morrison (Upper Jurassic) and Sundance Formations (Upper and Middle Jurassic)}

The Morrison and Sundance Formations (intervals 32 through 35) are composed of sandstone, siltstone, and claystone (Mills, 1956). Well cuttings indicate both formations are calcareous and contain some argillaceous limestone units. The Sundance Formation also contains glauconite. The density and porosity of intervals 32 and 33 of the Morrison Formation are similar to those of the overlying Cloverly Formation and Thermopolis Shale, while intervals 34 and 35 are more dense and less porous than all overlying intervals except intervals 3 through 7 in the upper part of the Frontier Formation.

Gypsum Spring (Middle Jurassic) and Popo Agie (Upper Triassic) Formations

Intervals 36 and 37 correspond to the Gypsum Spring and Popo Agie Formations. Well cuttings indicate that the upper part of the Gypsum Spring Formation is composed of calcareous shale and dolomite beds, and the lower part is anhydrite with interbedded claystone and sandstone at the base. The Popo Agie Formation consists of slightly to moderately calcareous mudstone with nodular and thin-bedded to lenticular limestone. Interval 37 encompasses lithologic units that presumably have a wide range of density and porosity.

\section{Crow Mountain Sandstone (Upper Triassic)}

In the area south of Thermopolis the Crow Mountain
Sandstone (intervals 38 through 41 ) consists of (1) an upper siltstone member with some fine-grained sandstone and claystone units and (2) a locally absent lower member of very fine to fine grained cross-stratified sandstone (Maughan, 1972). The gamma-ray log from the Gebo Unit No. 52 suggests that intervals 38 through 40 may correspond to the upper siltstone me $\eta$ ber and interval 41 may correspond to the lower sand tone member (sheet 3 ). Interval 39 may correlate with the part (Curtis sandstone of local usage) of the Crow Mountain Sandstone that produces oil in the nearby Gebo Unit No. 32. Interval 41 is described in drilling records from the Gebo oil field as a "brick red, mediumto fine-grained sandstone." Gamma-gamma density logs from wells in the Gebo field show this basal interval of the Crow Mountain Sandstone to be significantly less dense and more porous than adjacent interval- (sheet 3 ). Porosity development in the lower part of the Crow Mountain Sandstone is comparable to that of the overlying Pryor Conglomerate Member and Front:er Formation. The average density and porosity of the Crow Mountain Sandstone are $2.49 \mathrm{~g} / \mathrm{cm}^{3}$ and 9 percent respectively.

\section{Red Peak and Dinwoody Formations (Lower Triassic)}

The Red Peak Formation (intervals 42 throngh 44 ) is composed of red siltstone, claystone, and very fine grained sandstone (Maughan, 1972). Well cuttings indicate that the upper part of the Red Peak Formation (interval 42) is very calcareous, the middle part (interval 43 ) is slightly calcareous, and the lower part (interval 44 ) is dolomitic with inclusions of anhydrite. The Dinwoody Formation (interval 45) consists, in its upper portion, of anhydrite and anhydritic shale units with disseminated pyrite and, in its lower portion, of siltstone and sandstone units that probably are dolomitic or anhydritic (Maughan, 1972; Tourtelot, 1952; Mills, 1956; also see gamma-ray and gamma-gamma density logs of the Dinwoody Formation from the Gebo Unit No. 52, sheet 3). The high interval density of this formation is due to the presence of anhydrite, dolomite, and pyrite. The Red Peak and Dinwoody Formations have the lowest average porosity of all formations studied (fig. 3).

\section{Park City Formation (Permian)}

The Park City Formation (intervals 46 through 56) consists of units of finely crystalline dolomiti: limestone and dolomite that are partly argillaceous, locally cherty, and occasionally anhydritic (Mills, 1956). Interbeds of red and gray-green shale, chert, and anhydrite are irregularly present. On a regional basis the Park City Formation represents a marine carbonate facies that intertongues with the chert-mudstone-phosphorite facies of the Phosphoria Formation to the west and with the red-bed facies of the Goose Egg Formation to the east (Maughan, 1975, Fig. 2). Some of the interbe Ided units in the Park City Formation at Gebo presumatly are tongues of these adjacent facies. Exposures of the Park City Formation south of Thermopolis consist of dolomitic limestone and dolomite in the upper and lower 
parts with greenish-gray calcareous mudstone in the middle part (Maughan, 1972). Maughan also describes phosphorite beds less than 1 foot thick and bedded and nodular chert as much as 12 feet thick.

Well logs from the Gebo oil field show that individual units of the Park City Formation are lithologically continuous over the area of the field except for the lowermost beds that rest on the unconformity at the top of the Tensleep Sandstone.

Well logs and cuttings indicate that intervals 46 and 49 bracket units of finely crystalline dolomite. Interval 47 presumably corresponds to a glauconitic dolomite, possibly with thin interbeds of phosphatic shale, because of its high natural gamma-ray activity. These three most porous intervals constitute 41 feet of the Park City Formation and have an average density and porosity of $2.52 \mathrm{~g} / \mathrm{cm}^{3}$ and 16 percent respectively. Porosity development in these intervals may be due to vugs (reported in well cuttings), brecciation (Campbell, 1956), or fenestral fabric (Boyd, 1975).

Intervals 48, 50, and 51 encompass interbedded units of argillaceous or glauconitic dolomite and dolomitic shale. Small amounts of bedded or nodular chert probably are present. These intervals constitute 67 feet of the Park City Formation and have an average density and porosity of $2.69 \mathrm{~g} / \mathrm{cm}^{3}$ and 7 percent respectively.

Intervals 52 and 53 correspond to units of dolomite with interbeds of argillaceous dolomite. The very high density of these intervals suggests that anhydrite is present. Mees and Bowers (1952) report anhydrite in the Park City Formation at Gebo, and Frielinghausen (1952) reports dolomite with thin layers of finely crystalline anhydrite at Lucerne, T. 43 N., R. 94 W., near the Gebo field.

Interval 54 is described from well data in the Gebo field as "interbedded finely crystalline dolomite and shale." Well cuttings that correspond to this interval were reported to contain pyritic shale. Interval 55 brackets a dolomite unit-the lowest unit of the Park City Formation that is continuous throughout the Gebo oil field.

Units that correspond to the lower part of interval 56 and all of interval 57 are not laterally continuous over the Gebo oil field and presumably represent a filled channel of the ancient Tensleep erosion surface. 5 In most wells the top of the development of clean sand and porosity in the Tensleep Sandstone is located stratigraphically near the base of interval 56. However, the top of clean sand and porosity development occurs at the base of interval 57 in the Gebo Unit No. 28 and at the base of interval 58 in the Gebo Unit No. 52 (sheet 3). Well cuttings and conventional cores indicate that intervals 56 and 57 correspond, from top to bottom, to dolomitic shale, cherty conglomeratic sandstone, anhydritic and partly argillaceous dolomite with floating quartz sand grains, and dolomitic or anhydritic quartz sandstone.

Intervals 52 through 56 constitute the lower 120 feet of the Park City Formation and have an average density and porosity of $2.77 \mathrm{~g} / \mathrm{cm}^{3}$ and about 2 percent respectively.

\section{Tensleep Sandstone (Pennsylvanian)}

In the region of the Gebo oil field the Tensleep Sandstone (intervals 57 through 74) is composed of massive to crossbedded, generally slightly to moderately calcareous, fine- to medium-grained quartz sandstor with $^{-}$ some interbeds of dolomite and sandy dolomite (Mills, 1956; Maughan, 1972). Sandstone units vary locally in thickness, grain size, and type and abundance of cement. Sandstone lithology ranges from highly porous, friable units to well-cemented beds that resemble quartzite. Generally orthochemical quartz and dolomite are the dominant cementing minerals (Todd, 1963; Fox and others, 1975). Interbedded units of dolomite are most abundant near the base of the formation and cannot always be correlated from one well to another with well logs. Emmett and others (1971) provide a detailed study of the Tensleep Sandstone as an oil reservoir, in a setting similar to that of Gebo, in the Little Buffalo ]'asin oil field located about 50 miles northwest of the Gebo field.

The density fluctuations observed in the Tensleep Sandstone over intervals 58 through $7 \dot{4}$ range from $2.39 \mathrm{~g} / \mathrm{cm}^{3}$ to $2.73 \mathrm{~g} / \mathrm{cm}^{3}$ and are caused primarily by variations in porosity and abundance of dolomite. For example, descriptions of conventional cores irdicate that intervals 65 and 72 bracket dolomite beds sev aral feet thick that grade upward and downward into colomitic sandstone. Interval 67 corresponds to a relatively porous sandstone without significant carbonate cement.

The accuracy with which grain densities are estimated directly affects the accuracy of the porosity values calculated from interval densities (Supplement). Because dolomite has a significantly higher grain density than quartz, about $2.85 \mathrm{~g} / \mathrm{cm}^{3}$ versus $2.65 \mathrm{~g} / \mathrm{cm}^{3}$, variable and uncertain amounts of dolomite in the Tensleep Sandstone complicate the selection of average grain densities. In the absence of grain density measurements of conventional cores, the method described in figure 5 is used to determine interval grain density.

A summary of the porosity of the Tensleep Sandstone in the Gebo Unit No. 28 is given in figure 6. Fox and others (1975) predict an average porosity of $\varepsilon$ percent for the Tensleep in the area of the Gebo oil fiald and state that about 40 feet of Tensleep should have porosities greater than 8 percent. The average porosity of the 256 feet of Tensleep Sandstone surveyed in $\mathrm{tl}$ - Gebo Unit No. 28 is 7 percent and about 105 feet $\mathrm{cf}$ Tensleep section has a porosity greater than 8 percent.

5 Lawson and Smith (1966) discuss stream channels on the eroded Tensleep surface, before the transgression of the Permian sea, that wer: later filled with impervious basal Permian sediments. 


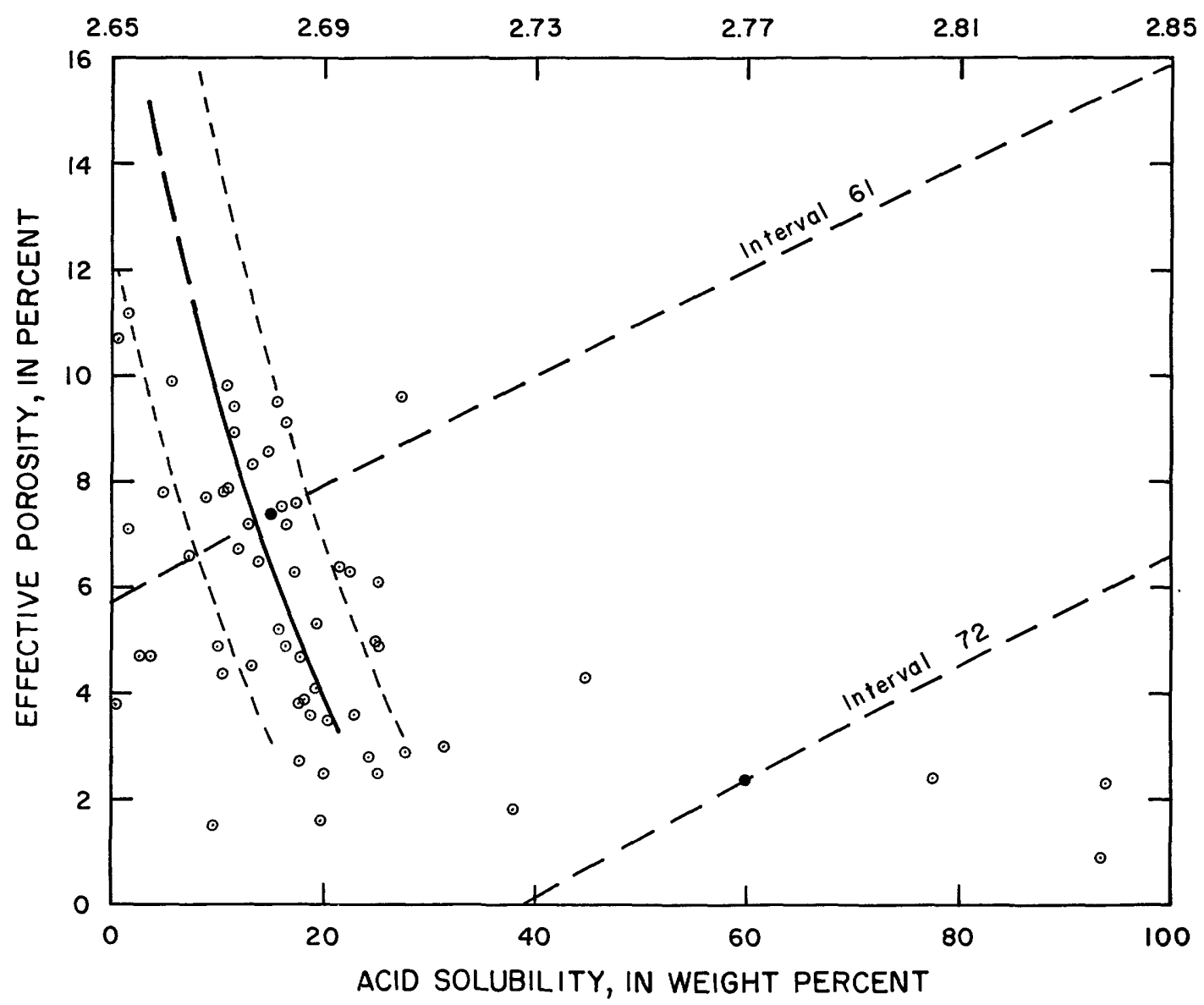

Figure 5.-Effective porosity versus acid solubility of conventional cores of Tensleep Sandstone taken from Gebo Unit No. 32. Average grain density, shown along upper horizontal scale, is based on assumption that acid-soluble part of the cores is dolomite. Generally the lower the weight percent of acid-soluble (carbonate) material, the higher the effective porosity, and vice versa. Scatter of points presumably is due in part to fact that quartz cement and degree of sorting also affect porosity.

Using equation for porosity given in Supplement and interval densities calculated from borehole gravity survey, lines corresponding to different intervals can be drawn on figure 5 . Lines labeled interval 61 and 72 are the lines of equations

and

$$
\bar{\phi}=100\left(2.556-\bar{\rho}_{\mathrm{g}}\right) /\left(1.00-\bar{\rho}_{\mathrm{g}}\right)
$$

$$
\bar{\phi}=100\left(2.728-\bar{\rho}_{\mathrm{g}}\right) /\left(1.00-\bar{\rho}_{\mathrm{g}}\right)
$$

where $\bar{\phi}$ is interval porosity in percent, $\bar{\rho}_{\mathrm{g}}$ is interval grain density in $\mathrm{g} / \mathrm{cm}^{3}, 1.00 \mathrm{~g} / \mathrm{cm}^{3}$ is assumed porefluid density, and $2.556 \mathrm{~g} / \mathrm{cm}^{3}$ and $2.728 \mathrm{~g} / \mathrm{cm}^{3}$ are densities of intervals 61 and 72 that were calculated from borehole gravity measurements. Solid dot on each line represents possible set of porosity and grain density values of the interval that seem to best fit core data. Thus, $2.68 \mathrm{~g} / \mathrm{cm}^{3}$ and $2.77 \mathrm{~g} / \mathrm{cm}^{3}$ are chosen for grain densities of intervals 61 and 72 and resultant interval porosities are 7.4 percent and 2.4 percent respectively. This procedure assumes that effective porosity of conventional cores is the same as interval or total porosity. 


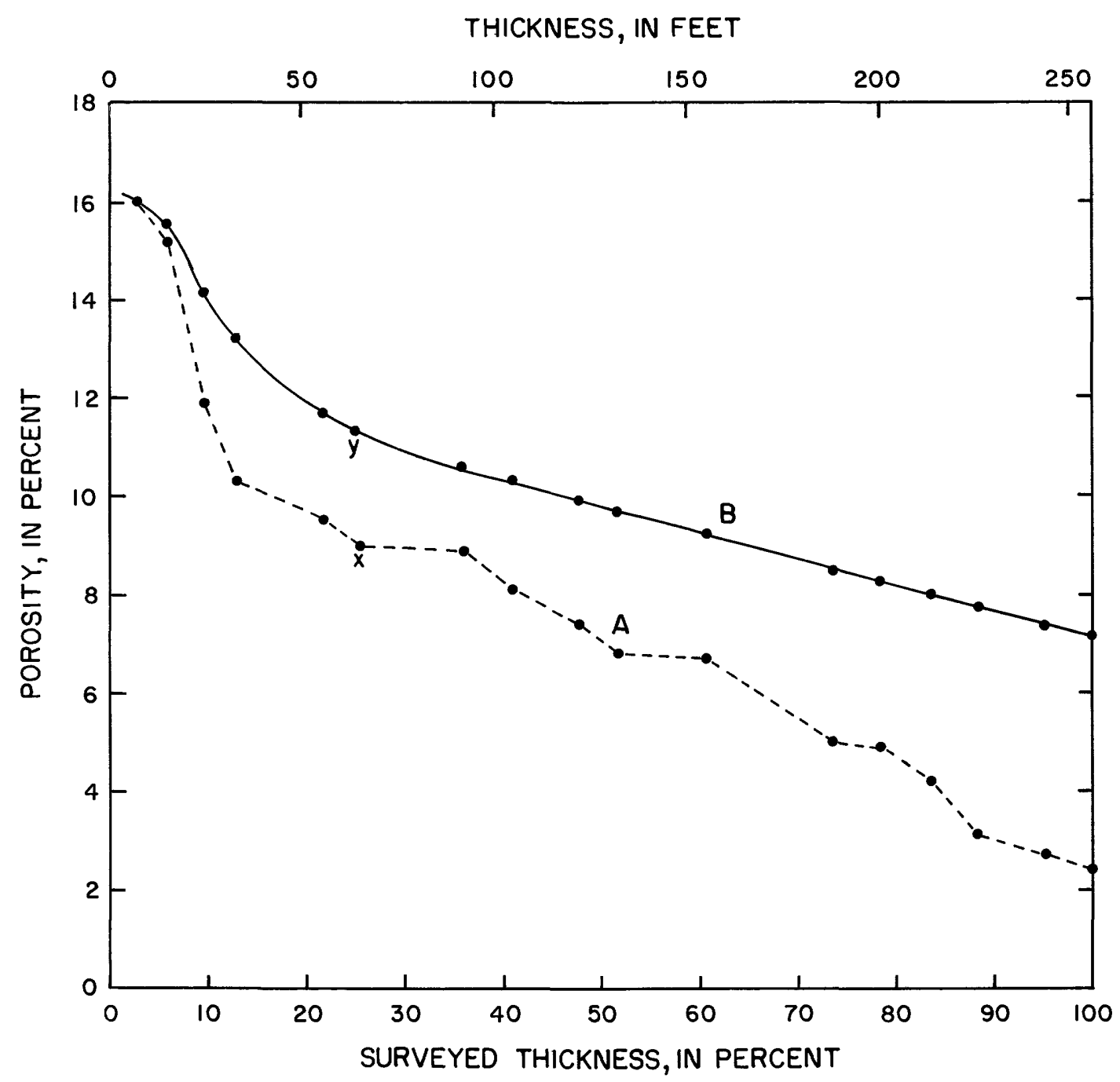

Figure 6. - Interval porosity versus percent of surveyed thickness of Tensleep Sandstone from Gebo Unit No. 28. Broken line $A$ is interval porosity versus percent of surveyed thickness. For example, point $x$ on line $A$ indicates that 25 percent or 64 feet of surveyed thickness has interval porosity values greater th an 9 percent. Curve B is average interval porosity versus percent of surveyed thickness. For example, point $y$ on curve B indicates that the average interval porosity of most porous 25 percent or 64 feet of surveyed thickness is slightly more than 11 percent.

\section{Discussion and conclusions}

The borehole gravity survey of the Gebo Unit No. 28 provides accurate and unique (gravimetric) large-volume estimates of the in-situ density of 5,083 feet of clastic, carbonate, and evaporite rocks that range in age from Pennsylvanian to Late Cretaceous. Interval density ranges from as low as $2.33 \mathrm{~g} / \mathrm{cm}^{3}$ for a porous sandstone unit in the Frontier Formation to as high as $2.80 \mathrm{~g} / \mathrm{cm}^{3}$ for a unit of anhydritic dolomite in the Park City Formation. The average density of the entire section is $2.55 \mathrm{~g} / \mathrm{cm}^{3}$. Interval porosity ranges as high as $15 \mathrm{per}$ cent to 21 percent for sandstone units in the Frontier, Cloverly, and Morrison Formations and in the Crow Mountain and Tensleep Sandstones. Some dolomite units in the upper part of the Park City Formation have interval porosities as high as 14 percent to 18 percent. The average porosity of the entire section is 8.6 percent.
(1) Cretaceous sandstones and shales penetrated by the Gebo Unit No. 28 have lower maximum porosities than would be predicted by their present depths of $t$ 'rial and therefore are "overcompacted." Sandstone bed in the Frontier Formation at depths of 1,500 to 2,000 feet in the Gebo Unit No. 28 have maximum average forosities of about 21 percent to 24 percent (Baptist and others, 1952 , and this study). McCulloh (1967, fig. 4) predicts that reservoir beds of sandstone with these values of "probable maximum average porosity" occur at depths of about 6,000 to 8,000 feet. Cretaceous shales at depths of 800 to 2,850 feet in the Gebo Unit N'?. 28 have porosities that reach about 15 percent to 20 percent. Studies of shale porosity with depth as summarized by Rieke and Chilingarian (1974, fig. 17) sugge't that shales with maximum porosities of 10 percent to 20 
percent normally occur at depths at least twice those of the Cretaceous shales at Gebo. Other evidence supports the proposition that the Cretaceous sandstones and shales at Gebo are overcompacted. Approximately 5,500 to 8,500 feet of predominantly nonmarine rocks that range in age from latest Cretaceous through at least Eocene or Oligocene is thought to have been present in the southern Big Horn Basin before removal by late Cenozoic erosion (Mackin, 1947; Jepsen and Van Houten, 1947; Van Houten, 1952; Rocky Mtn. Assoc. Geologists, 1972, p. 219). Properties of coal samples from the nearby Gebo coal field (Glass and others, 1975 ) indicate that the maximum depth of burial exceeded present depths by more than several thousands of feet (N. Bostick, oral commun. 1977; insufficient knowledge of the thermal history of the section during the period of maximum burial precludes more definitive burial estimates from the coal properties). Compaction effects are difficult to assess in the pre-Cretaceous section because, in the case of older rocks at any depth of burial, chemical reactions are the dominant processes of burial diagenesis.

(2) The Frontier Formation, Mowry Shale, and Shell Creek Member of the Thermopolis Shale are, on the average, about 5 porosity percent more porous than the overlying Cody and underlying Thermopolis Shales (fig. 3 and sheet 2). The higher porosity and lower density of these formations probably is partly due to the presence of bentonite, which is absent from the underlying Thermopolis Shale and is only a minor constituent of the overlying Cody Shale. Bentonite is composed mostly of montmorillonitic clays and colloidal silica and is capable of retaining large quantities of absorbed water. Nodular siderite and a high illite-to-montmorillonite ratio characterize the Cody Shale (Siemers, 1975) and presumably contribute to its relatively high density. The low-porosity rocks of intervals 3 through 7 , and possibly the lower part of the Cody Shale, may have formed a barrier to the upward expulsion or migration of pore fluids from the underlying Frontier, Mowry, and Shell Creek rocks.

(3) The pronounced change in density and porosity from intervals 3 to 11 in the Frontier Formation is due partly or wholly to the downward decrease in glauconite and porosity-occluding calcite cement in the sandstone and shale, which probably indicates a change in depositional environment. The relatively low porosity sandstone of intervals 3 through 7 is glauconitic and calcareous and contains thin conglomerate beds and shale inclusions. Thin interbeds of shale also are present. These units may correspond to a series of marginalmarine progradational sands and lag gravels associated with the marine transgression before deposition of the overlying Cody Shale (Ryer, 1977). Siemers (1975) observed glauconite in what he interprets as marine and marginal-marine sandstone but not in nonmarine deltaic sediments in outcrops of the Frontier in the northwest part of the Big Horn Basin. Also, porosityoccluding calcite cement often indicates calcitic skeletal material in or near the site of deposition, further evidence to support a marine or marginal-marine origin for this conglomeratic sandstone (for example,
Jacka, 1970). Beneath these low-porosity rocks, the relatively high porosity soft sandstone and shale of intervals 9,10 , and 11 is partly carbonaceous, partly bentonitic, and noncalcareous. E. A. Merewether (written commun., 1977) reports carbonaceous material in this part of the Frontier section ex yosed near Thermopolis. This lower sequence probably represnts a delta-margin environment, as proposed by Siemers (1975) for similar units of the Frontier Formation in the northwest part of the Big Horn Basin.

(4) Merewether and others (1975, table 1, fig. 7) proposed an unconformity in the upper part of the Frontier Formation in the Gebo area for which they believe section is missing for as much as the sacond half of Cenomanian time and most of Turonian time, a period of about 5 million years (Obradovich and Cobban, 1975). This unconformity is located at about 1,400 feet in the Gebo Unit No. 28 and at abnut 1,430 feet in the Gebo Unit No. 52, based on the surface and subsurface control used by Merewether and $c^{\text {thers }}$ (1975) to construct their figure 7. Correlation of this unconformity with the abrupt change in density and porosity from interval 7 to interval 9 is inescapable. The coincidence of this unconformity and the top of porosity development in the Frontier Formation may be widespread in the Big Horn Basin and may be a mappable seismic horizon if, as one would expect, the abrupt change in density is accompanied by a significant change in compressional wave velocity. Formation density and porosity logs may provide the be $t$ means for locating this unconformity in the subsurface. Note the response of the gamma-gamma density lo: from the Gebo Unit No. 52 at and near 1,430 feet (sheet 3).

(5) The lowest values of interval density logged in the Frontier Formation (intervals 9, 10, 14, and 19) correspond to units for which the lowest natural g^mma-ray activity is recorded (sheet 3 ). These units are the most porous, least clayey sandstone in the Frontie.; and one or more of them may be the source of the shows of green oil reported during drilling of wells in the Gebo oil field. Porosities of individual beds within these intervals undoubtedly range over slightly broader limits. For example, porosities of core samples range from 12 percent to 24 percent and average 19 percent for sandstone in the Frontier from a depth range of 687 feet to 1,031 feet in the Grass Creek oil field, located about 22 miles northwest of the Gebo field (Baptist an 7 others, 1952). Porosity development in the Muddy Sandstone Member of the Thermopolis Shale is considerably less ( 5 percent to 10 percent) than in the Pryor Con Member of the Cloverly Formation, the upper sandstone of the Morrison Formation, and the Crow Mountain Sandstone (12 percent to 18 percent).

(6) Similar densities and porosities are noted for units of differing ages and depths of burial. The upper shale of the Cloverly Formation has a density and porosity similar to the density and porosity of the Mowry Shale and Shell Creek Member of the Thermopolis Shale. The Thermopolis Shale, Cloverly Formation, and upper shale unit of the Morrison Formation (interval 32) have densities and porosities similar to those of the Cody 
Shale. Presumably the shale units within each of these groups have some common characteristics that help to explain their similar densities and porosities. Compaction effects probably do not significantly alter these comparisons, because the rates of change of density and porosity with depth have been decreased considerably by the additional overburden that previously existed at Gebo.

(7) Units opposite intervals 32 and 33 in the upper part of the Morrison Formation have densities and porosities similar to those of the overlying Cloverly Formation and Thermopolis Shale. These units probably belong to the depositional sequence represented by the Cloverly Formation rather than to the sequence of older, underlying units of the Morrison Formation. Well cuttings indicate that a pebbly sandstone occurs near the base of interval 33 .

(8) The difference in density between oil and formation water in the Tensleep Sandstone is small because Tensleep oil has a relatively low API gravity and low gas-oil ratio. This conclusion also is valid for oil and formation water in the Park City Formation. Consequently, interval density in the Tensleep and Park City reservoirs is not appreciably affected by variations in oil saturation but varies in response to fluctuations of porosity and mineralogy.

(9) Measurements made by the unit operator using samples of conventional cores taken from the Tensleep Sandstone indicate that porosity generally decreases as the proportion of acid-soluble mineral constituents increases (fig. 5). The measurements are used to improve the accuracy of the conversion of interval density to interval porosity in the Tensleep reservoir where the two primary mineral constituents, quartz and dolomite, have significantly different grain densities. Average mineral grain density is estimated from weight percent of acidsoluble constituents by assuming that dolomite is the only acid-soluble mineral present. The resultant empirical relationship between effective porosity and average grain density of core samples is used to convert gravimetrically-determined interval density to interval porosity.

(10) Natural fractures are reported in conventional cores taken from various parts of the Tensleep Sandstone in the Gebo oil field. Based on the extent of fracturing described in core samples, the magnitude of fracture porosity is very small when compared with the magnitude and variations of intergranular porosity. Even if small effects due to fracturing contribute in a measurable way to interval porosity, they probably are completely masked by fluctuations of intergranular porosity due to variations in cementation or replacement by dolomite. Although intergranular and fracture porosity are not separable in this study, the density and porosity data provided here may be useful, in an empirical way, for predicting the occurrence of natural fractures or estimating the susceptibility of various parts of the Tensleep reservoir to successful stimulation by hydraulic fracturing. Because borehole gravity examines large volumes of rock adjacent to the well, quantitative evaluation of fracture porosity may be possible with borehole gravity measurements in some highly f-actured, relatively homogeneous reservoirs where intergranular porosity can be estimated accurately from core studies.

(11) Several near-vertical zones characterized by relatively high permeability and water production in the Tensleep reservoir cut obliquely across the Gebo anticline. These zones are believed to be characterized by more extensive open fractures than are generally found throughout the Tensleep reservoir. A zone of this type is located several hundred feet northwest of the Gebo Unit No. 28 and is included in the region of investigation of the borehole gravity survey. Although the effects of this zone on the density and porosity data are unknown, they are believed to be small or negligible, partly because of the reasons given in the preceding paragraph and partly because of the limited volume of the fracture zone and its distance from the Gebo Unit No. 28.

(12) Qualitative comparison is possible between the interval density profile from the Gebo Unit No. 28 and the gamma-gamma density log from the Gebo Unit No. 52 , in one case, and between the interval porosity profile from the Gebo Unit No. 28 and the neutron porosity logs from the Gebo Unit Nos. 28 and 52, in the second case, provided several important points are remembered: (1) The gamma-gamma density log responds to electron density and the neutron porosity log responds to abundance of hydrogen in the annular region that extends 1 to 2 feet outward from the logging tool; (2) the borehole gravimeter responds to an integrated effect of mass/ volume that extends outward tens to hundreds of feet from the borehole; (3) the gamma-gamma density and neutron porosity logs are continuous types of loogs that practically always give more vertical resolution than the discontinuous, interval-averaging density and porosity profiles calculated from a borehole gravity survey; and (4) some rock units in the section are known to display lateral variations in lithology, density, and porosity between the Gebo Unit Nos. 28 and 52. The interval density profile and the gamma-gamma density log agree fairly well except where borehole rugosity or ravid change in borehole diameter perturbs the gamma-gamma $\log$. Erroneously low estimates of formation dersity on the gamma-gamma log that occur opposite inter'al 3 and immediately above intervals 3 and 24 are primarily due to the borehole rugosity that is evident on the crliper log. The discrepancy between interval 58 and the gamma-gamma log is caused by lateral variations of lithology between the Gebo Unit Nos. 28 and 52. Large differences exist between the interval porosity profile and the neutron porosity logs except for certair intervals in the Crow Mountain Sandstone, Park City Formation, and Tensleep Sandstone. At shallower depths the anomalously large borehole diameter and its associated effects are mainly responsible for the erroneously high porosity of the neutron log. Chemically bound water (hydrogen) in gypsum and clays (especially bentonite) also causes erroneously high porosities on the neutron log (Savre and Burke, 1963) and may contribute to the ot served differences between the interval porosity profile and neutron porosity log in portions of the Frontier Formation, Muddy Sandstone Member of the Thermonolis 
Shale, and Park City Formation. The cased-hole neutron $\log$ from the Gebo Unit No. 28 also may be perturbed in the Park City Formation by possible cement behind the casing and voids caused by acid treatment of the carbonate reservoir.

(13) Suites of modern well logs play a very important role in the planning and interpretation of borehole gravity surveys. For example, well logs from the Gebo Unit No. 28 were used exclusively during the planning stage of the present study. Subsequent comparison of the survey results with the higher quality, more detailed well logs from the nearby Gebo Unit No. 52 indicate shortcomings in the logging program (sheet 3): (a) interval 11 should have been logged as two intervals to differentiate between the upper, softer sandstone units and the lower, better indurated, more clayey units; (b) the Muddy Sandstone Member should have been logged with three instead of two intervals; and (c) the Crow Mountain Sandstone should have been surveyed with more and better placed intervals.

\section{REFERENCES CITED}

Baptist, O. C., Smith, W. R., Cordiner, F. S., and Sweeney, S. A., 1952, Physical properties of sands in the Frontier Formation, Big Horn Basin, Wyoming: Wyoming Geol. Assoc. Guidebook, 7th Ann. Field Conf., p. 67-73.

Beyer, L. A., 1971, The vertical gradient of gravity in vertical and near-vertical boreholes: U.S. Geol. Survey Open-file Rept., 229 p.

Beyer, L. A., and Corbato, C. E., 1972, A FORTRAN IV computer program for calculating borehole gravity terrain corrections: U.S. Geol. Survey, Menlo Park, Calif., 30 p., available from NTIS, Springfield, Va., (PB2-08679).

Biggs, Paul, and Espach, R. H., 1960, Petroleum and natural gas fields in Wyoming: U.S. Bureau Mines Bull. 582, p. 109-110, 294.

Boyd, D. W., 1975, Fenestral fabric in Permian carbonates of the Big Horn Basin, Wyoming: Wyoming Geol. Assoc. Guidebook, 27th Ann. Field Conf., p. 101-106.

Bradley, J. W., 1976, The commercial application and interpretation of the borehole gravimeter, in Jantzen, R. E., ed., Tomorrow's oil from today's provinces: Am. Assoc. Petroleum Geologists Misc. Pub. 24, p. 98-109.

Campbell, C. V., 1956, The Phosphoria Formation in the southeastern Big Horn Basin, Wyoming: Stanford Univ., Stanford, Calif., Ph. D. thesis, 178 p.

Cobban, W. A., and Reeside, J. B., Jr., 1952, Frontier Formation, Wyoming and adjacent areas: Am. Assoc. Petroleum Geologists Bull., v. 36, no. 10, p. 1913-1961.

Cupps, C. Q., and Fry, J., 1967, Reservoir oil analysis, Gebo field, Wyoming: U.S. Bureau Mines Open-file Rept. OFR 4-67, 16 p.

Curry, W. H., 1962, Depositional environments in central Wyoming during the Early Cretaceous: Wyoming Geol. Assoc. Guidebook, 17th Ann. Field Conf., p. 118-123. Emmett, W. R., Beaver, K. W., and McCaleb, J. A., 1971, Little Buffalo Basin Tensleep heterogeneity-Its influence on drilling and secondary recovery: Jour. Petroleum Technology, Feb. 1971, p. 161-168.

Fox, J. E., Lambert, P. W., Mast, R. F., Nuss: N. W., and Rein, R. D., 1975, Porosity variation in the Tensleep and its equivalent the Weber Sandstone, Western Wyoming: A log and petrographic analysis, in Bolyard, D. W., ed., Deep drilling frontiers of the central Rocky Mountains: Denver, Colo., Rocky Mountain Assoc. of Geologists, p. 185-215.

Frielinghausen, K. W., 1952, The Phosphoria Formation of southern and southeastern Big Horn Basin, Big Horn, Hot Springs and Washakie Counties, Wyoming: Wyoming Geol. Assoc. Guidebook, 7th An?. Field Conf., p. 54-57.

Glass, G. B., Westervelt, Katherine, and Oviatt, C. G., 1975, Coal mining in the Big Horn coal basin of Wyoming: Wyoming Geol. Assoc. 27th Ann. Field Conf. Guidebook, p. 221-228.

Goodell, H. G., 1962, The stratigraphy and retrology of the Frontier Formation of Wyoming: Wyoming Geol. Assoc. Guidebook, 17 Ann. Field Conf., p. 173-210. Horn, G. H., 1963 Geology of the East Thermopolis Area, Hot Springs and Washakie Counties, Wyoming: U.S. Geol. Survey Oil and Gas Invest. Map OM-213.

Hunter, L. D., 1952, Frontier Formation along the eastern margin of the Big Horn Basin, Wyoming: Wyoming Geol. Assoc. Guidebook, 7th Ann. Field Conf., p. 63-66, 3 pl.

Jacka, A. D., 1970, Principles of cementation and porosity occlusion in Upper Cretaceous sandstones, Rocky Mountain region: Wyoming Geol. A ssoc. Guidebook, 22nd Ann. Field Conf., p. 265-285.

Jageler, A. H., 1976, Improved hydrocarbon reservoir evaluation through use of borehole-gravimeter data: Jour. Petroleum Technology, v. 28, no. 6, p. 709-718.

Jepsen, G. L., and Van Houten, F. B., 1947, Early Tertiary stratigraphy and correlations: Wyoming Geol. Assoc. Guidebook, 2d Ann. Field Conf., p. 142-149.

Keefer, W. R., 1972, Frontier, Cody and Me-averde Formations in the Wind River and souther' Big Horn Basins, Wyoming: U.S. Geol. Survey Prof. Paper 495-E, $23 \mathrm{p}$.

Lawson, D. E., and Smith, J. R., 1966, Pennylvanian and Permian influence on Tensleep oil accumulation, Big Horn Basin Wyoming: Am. Assoc. Petroleum Geologists Bull., v. 50, no. 10, p. 2197-2220.

Mackin, J. H., 1947, Altitude and local relief of the Big Horn area during the Cenozoic: Wyoming Geol. Assoc. Guidebook, 2d Ann. Field Conf., p. 103-120.

McCulloh, T. H., 1966, The promise of precise borehole gravimetry in petroleum exploration and exploitation: U.S. Geol. Survey Circ. 531, 12 p.

1967, Mass properties of sedimentary rocks and gravimetric effects of petroleum and natural-gas reservoirs: U.S. Geol. Survey Prof Paper 528-A, 50 p. McCulloh, T. H., Kandle, J. R., and Schoellh amer, J. E., 1968, Application of gravity measurements in wells to problems of reservoir evaluation: Trans. 9th Ann. Logging Symp. of Soc. Prof. Well Log Analysts, June 23-26, 1968, p. O1-O29.

Maughan, E. K., 1972, Geologic map of the Wedding of 
the Waters quadrangle, Hot Springs County, Wyoming: U.S. Geol. Survey Geol. Quad. Map GQ-1042, scale $1: 24,000$.

1975, Organic carbon in shale beds of the Permian

Phosphoria Formation of eastern Idaho and adjacent states-A summary report: Wyoming Geol. Assoc. Guidebook, 27th Ann. Field Conf., p. 107-1 15.

Mees, E. C., and Bowers, G. F., 1952, Gebo field, Hot Springs County, Wyoming: Oil and Gas Journal, v. 51, no. 29, November 24, 1952, p. 125-127.

Merewether, E. A., Cobban, W. A., and Ryder, R. T., 1975. Lower Upper Cretaceous strata, Big Horn Basin, Wyoming and Montana: Wyoming Geol. Assoc. Guidebook, 27th Ann. Field Conf., p. 73-84.

Mills, N. K., 1956, Subsurface stratigraphy of the preNiobrara formations in the Big Horn Basin, Wyoming: Wyoming Geol. Assoc., Wyoming Stratigraphy, Part 1, p. 9-22.

Obradovich, J. D., and Cobban, W. A., 1975, A time scale for the Late Cretaceous of the western interior of North America: Geol. Assoc. Canada Spec. Paper No. 13 , p. 31-54.

Paull, R. A., 1962, Depositional history of the Muddy Sandstone, Big Horn Basin, Wyoming: Wyoming Geol. Assoc. Guidebook, 17th Ann. Field Conf., p. 102-117.

Rasmussen, N. F., 1973, Borehole gravity survey planning and operations: Trans. 14th Ann. Logging Symp. of Soc. Prof. Well Log Analysts, May 6-9, 1973, Lafayette Louisiana, P. Q1-Q28.

Rieke, H. H., III, and Chilingarian, G. V., 1974, Developments in Sedimentology 16: Compaction of argillaceous sediments: New York, Elsevier, 424 p.

Rocky Mountain Association of Geologists, 1972, Geologic atlas of the Rocky Mountain region: Denver, A. B. Hirschfield Press, 331 p.

Ryer, T. A., 1977, Patterns of Cretaceous shallowmarine sedimentation, Coalville and Rockport areas, Utah: Geol. Soc. America Bull., v. 88 , no. 2, p. 177-188.

Savre, W. C., and Burke, J. A., 1963, Determination of true porosity and mineral composition in complex lithologies with the use of the sonic, neutron, and density surveys: Trans. 4th Ann. Logging Symp. of Soc. Prof. Well Log Analysts, May 1963, Oklahoma City, Okla. p. XI1-XI35.

Siemers, C. T., 1975, Paleoenvironmental analysis of the Upper Cretaceous Frontier Formation, northwestern Big Horn Basin, Wyoming: Wyoming Geol. Assoc. Guidebook, 27th Ann. Field Conf., p. 85-100.

Smith, N. J., 1950, The case for gravity data from boreholes: Geophysics, v. 15, no. 4, p. 605-636.

Stone, D. S., 1967, Theory of Paleozoic oil and gas accumulation in the Big Horn Basin, Wyoming: Am. Assoc. Petroleum Geologists Bull., v. 51, no. 10, p. 2056-2114.

Taylor, B. N., and Cohen, E. R., 1973, The 1973 least squares adjustment of the fundamental constants: Jour. Physical and Chemical Reference Data, U.S. Nat. Bur. Standards, v. 2, no. 4, p. 663-734.

Todd, T. W., 1963, Post-depositional history of Tensleep Sandstone (Pennsylvanian), Big Horn Basin, Wyoming:
Am. Assoc. Petroleum Geologists Bull., v. 47, no. 4, p. 599-616.

Tourtelot, H. A., 1952, Marine and evaporite facies of Permian and Triassic strata in the southern part of the Big Horn Basin and adjacent areas, central Wyoming: Wyoming Geol. Assoc. Guidebook, 7th Ann. Field Conf., p. 49-52.

Van Houten, F. B., 1952, Sedimentary record of Cenozoic orogenic and erosional events, Big Horn Basin, Wyoming: Wyoming Geol. Assoc. Guidebook, 7th Ann. Field Conf., p. 74-79.

1962, Frontier Formation, Bighorn Basir. Wyoming: Wyoming Geol. Assoc. Guidebook, 17th Ann. Field Conf., p. 221-231.

Weitz, J. L., and Love, J. D., 1952, Geologic map of the southern Big Horn Basin, Wyoming: Wyoming: Geol. Assoc. Guidebook, 7th Ann. Field Conf., in pocket.

Wyoming Geological Association, 1957, Symporium on Wyoming oil and gas fields, with Supplement (1961), 579 p.

Zapp, A. D., 1956, Structure contour map of th 9 Tensleep Sandstone in the Big Horn Basin, Wyoming and Montana: U.S. Geol. Survey Oil and Gas Invert. Map OM-182, scale 1:250,000. 


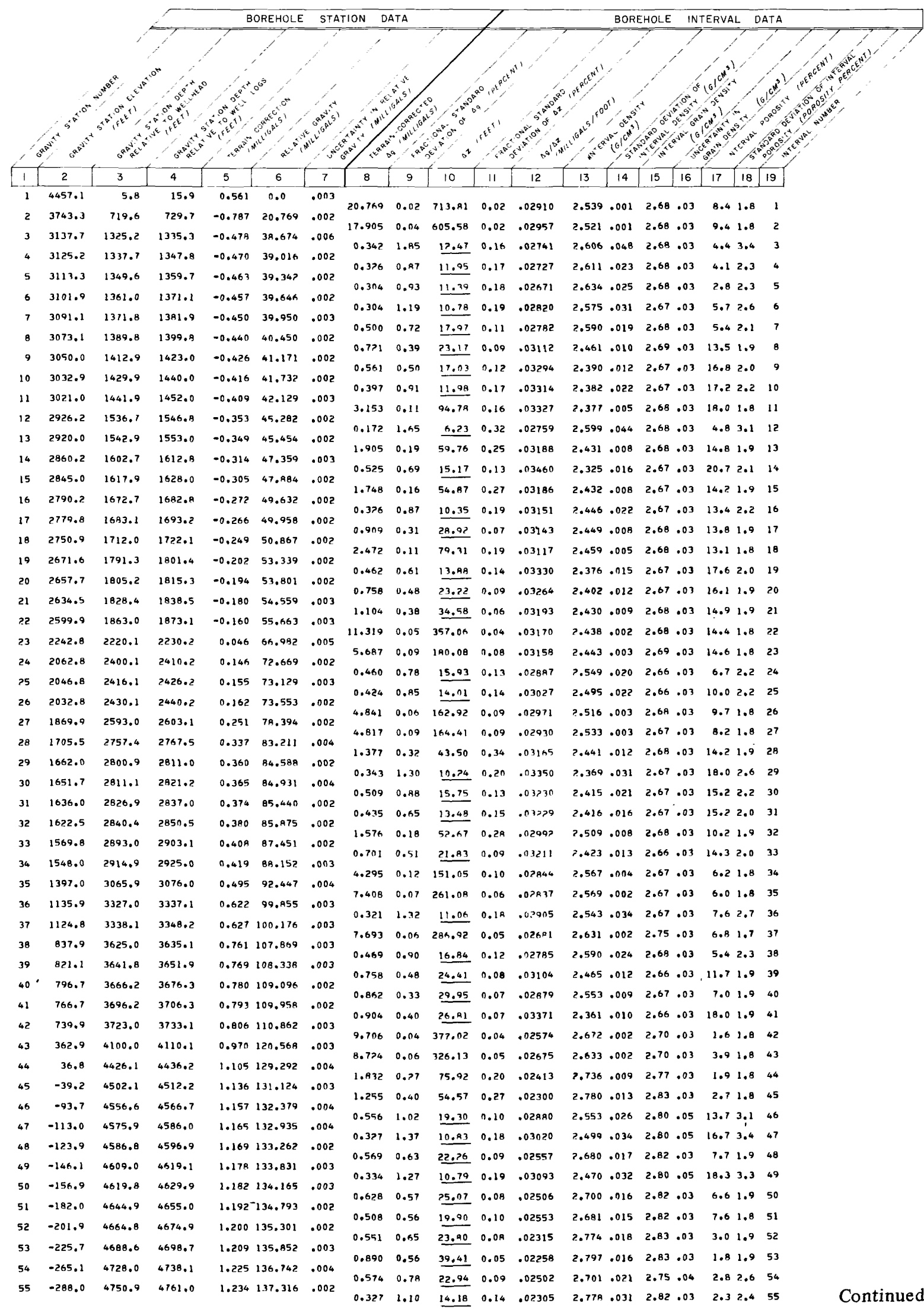




\begin{tabular}{|c|c|c|c|c|c|c|c|c|c|c|c|c|c|c|c|c|c|c|}
\hline & -302.2 & 4765.1 & 4775.2 & .239 & 137.643 & 003 & 0.450 & 0.94 & 19.57 & 0.10 & .02299 & 2.781 & .026 & 2.82 & .03 & 2.2 & 2.2 & 56 \\
\hline 5 & -321.8 & 4784.7 & $794 . A$ & 247 & 138.093 & & 1.023 & 0.35 & 42.16 & 0.05 & .02427 & 2.731 & .010 & 2.77 & .03 & 2.2 & 1.8 & 57 \\
\hline 5 & $\begin{array}{l}-363.9 \\
-386.9\end{array}$ & 826.8 & 36.9 & 263 & 139.116 & & 0.686 & 0.78 & 22.97 & 0.09 & .02987 & 2.512 & .020 & 2.67 & .01 & 9.5 & 1.3 & $\theta$ \\
\hline 60 & $\begin{array}{l}-386.9 \\
-397.0\end{array}$ & 4859.9 & 4870.0 & .275 & 140.090 & .003 & $0.28 B$ & 2.03 & 10.10 & 0.20 & .02840 & 2.565 & .052 & 2.68 & .01 & 6.8 & 3.2 & 59 \\
\hline 6. & -409.3 & 4872.2 & 4882.3 & .280 & 140.418 & .002 & & & 12.31 & & .02664 & 2.638 & .029 & 2.69 & .02 & 3.1 & 2.1 & 60 \\
\hline 62 & -426.7 & 4889.6 & 4899.7 & 1.287 & 140.916 & .002 & & & & 0.12 & .0287 & & .015 & & .01 & 7.4 & 1.1 & 61 \\
\hline 63 & -439.2 & 4902.1 & 4912.2 & 1.291 & 141.259 & .002 & & & & .16 & 年 & .607 & .022 & 69 & .01 & . & 1.4 & \\
\hline & -472.1 & 4935.0 & 4945.1 & 1.304 & 142.164 & .002 & & 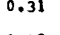 & & 6 & 2748 & 5 & .008 & 69 & .01 & 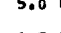 & .8 & \\
\hline 5 & -495.1 & 4950.0 & 4968.1 & 1.312 & 142.819 & .002 & & $\theta$ & & 0.0 & 02844 & 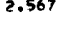 & 011 & 68 & .01 & & .9 & \\
\hline 36 & -512.9 & $4975 . \theta$ & 4985.9 & 1.319 & 143.276 & .002 & & 0.62 & .76 & 0.1 & 025 & 673 & .017 & $7 \bar{e}$ & .02 & & .3 & \\
\hline 67 & -525.7 & 4988.6 & 4998.7 & 1.324 & 143.651 & .003 & & 0.96 & 92 & 0.1 & 2292 & 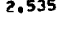 & .025 & 7 & $\cdot 0$ & & 6 & \\
\hline 68 & -533.7 & 4996.6 & 5006.7 & 1.327 & 143.912 & .003 & 2 & 1.63 & 3.01 & 0.2 & 132 & 2.407 & .040 & 2.66 & .01 & & 5 & \\
\hline 69 & -542.0 & 5004.9 & 5015.0 & 1.330 & 144.162 & .002 & & 1.44 & 8.28 & 0.24 & 030 & 2.499 & .037 & 2.67 & .01 & & 3 & \\
\hline 70 & -554.9 & 5017.8 & 5027.9 & 1.335 & 144.512 & .002 & & 0.81 & 12.90 & 0.16 & .02713 & & .022 & & .01 & & .4 & \\
\hline 71 & -582.7 & 5045.6 & 5055.7 & 1.345 & 145.335 & .004 & & & 27.78 & 0.07 & 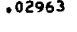 & 2.521 & .014 & 2.67 & .01 & & 1.0 & \\
\hline 72 & -589.9 & 5052.8 & 5062.9 & 1.348 & 145.573 & .002 & & 1000 & 7.24 & $0.2 B$ & .03287 & 2.394 & .045 & 2.66 & .01 & 16.0 & 2.8 & \\
\hline 73 & -602.3 & 5065.2 & 5075.3 & $1.35 ?$ & 145.875 & .002 & & 0.94 & 12.39 & 0.16 & .02435 & 2.728 & .026 & 2.77 & .02 & 2.4 & 1.9 & 2 \\
\hline 7 & -611.8 & 5074.7 & 5084.8 & 1.356 & 146.168 & .002 & & 0.96 & 9.49 & 0.21 & .03090 & 2.471 & .024 & 2.67 & .01 & 11.9 & 1.6 & \\
\hline 75 & -620.0 & 5082.9 & 5093.0 & 1.359 & 146.413 & .003 & & 1 & .25 & 0.24 & & 9 & 038 & 2.67 & .01 & 9. & 2.3 & \\
\hline 1 & 2 & 3 & 4 & 5 & 6 & 7 & 8 & 9 & 10 & 11 & 12 & 13 & 14 & 15 & 16 & 17 & 18 & 19 \\
\hline
\end{tabular}

\section{COLUMN 1}

Sequential numbers for 75 borehole gravity stations.

\section{COLUMNS 2, $3 \& 4$}

Gravity station elevations and borehole depths were calculated from cable length measurements and the references given below. The calibration of the cable measuring sheave is believed to be accurate to 0.03 percent or better, b?sed on many tests with the well-conditioned logging cable. Elevation and depth data were not corrected for borehole deviation from the vertical.

Reference
Kelly bushing
Top of working flange
Top of lower flange
MAT
Uppermost gravity station

\begin{tabular}{c} 
Elevation in feet \\
\hline $4473 *$ \\
$4462.9^{* *}$ \\
4461.9 \\
4461 \\
4457.1
\end{tabular}

* Depth datum for well logs.

** Depth datum for borehole gravity survey.

\section{COLUMN 5}

Terrain corrections were calculated by the method described by Beyer and Corbato (1972) for topography that extends 166.7 kilometers (103.6 miles) outward from the well. The density of the topography was assumed to be $2.50 \mathrm{~g} / \mathrm{cm}^{3}$.

\section{COLUMNS $6 \& 7$}

Values of borehole gravity adjusted to an assumed zero value for the uppermost gravity station. These values are corrected for gravimeter calibration, predicted tidal gravity fluctuations, terrain effects, and gravimeter drift as reconstructed from repeated measurements made at a wellhead base station and eight downhole stations.

Uncertainty in relative gravity is the sum of the uncertainties associated with (1) repeatability of individual gravimeter readings, (2) evaluation of gravimeter drift corrections, and (3) calculation of terrain corrections. In a practical s?nse, uncertainty as used here can be thought of as the maximum likely variation of a gravity value relative to the values of gravity at the two adjacent borehole gravity stations located above and below the station of consideration. Unce-tainty is used as an approximate measure of the standard deviation of relative gravity in the error analysis described below.

\section{COLUMNS $8 \& 9$}

$\Delta \mathrm{g}$ is obtained by forming the difference between successive pairs of values of relative gravity.

Fractional standard deviation of $\Delta \mathbf{g}$, expressed as a percentage, is the square root of the sum of the squares of the uncertainties of the relative gravity values divided by $\Delta \mathrm{g}$. For example, the fractional standard deviation for the twenty-seventh value of $\Delta \mathrm{g}$ is

$$
100 \sqrt{(.002)^{2}+(.004)^{2}} / 4.817=0.09 \text { percent }
$$




\section{COLUMNS $10 \& 11$}

Distances between adjacent borehole stations $(\Delta z)$ were determined in one of two ways. Values of $\Delta z$ less than $\mathbf{5 0}$ feet were measured by hand-chaining flagged cable lengths under load between the winch and wellhead. Hand-chair ed $\Delta \mathbf{z}$ values are repeatable to the nearest 0.02 feet and are underlined in the tabulation. Values of $\Delta z$ greater than 50 feet were determined from successive odometer readings of the cable measuring sheave and are repeatable to about 0.15 feet, based on many comparisons with hand-chained cable lengths. It was assumed that cable movement at the ground surface accurately reflected movement of the logging tool in the borehole.

Fractional standard deviation of $\Delta \mathbf{z}$ expressed as a percentage is the quotient of the repeatability divided by $\Delta \mathbf{z}$. For example, fractional standard deviation for the twenty-seventh value of $\Delta \mathrm{z}$ is

$$
100(0.15 / 164.41)=0.09 \text { percent }
$$

and for the twenty-ninth value of $\Delta \mathrm{z}$ is

$$
100(0.02 / 10.24)=0.20 \text { percent }
$$

\section{COLUMN 12}

Gravity difference $(\Delta \mathrm{g})$ divided by depth difference $(\Delta \mathrm{z})$ is the interval vertical gradient of gravity.

\section{COLUMNS $13 \& 14$}

Interval density $(\bar{\rho})$ was calculated with the equation

$$
\bar{\rho}=(1 / 4 \pi k)(F-\Delta g / \Delta z)
$$

where $\mathrm{k}$ is the Newtonian gravitational constant and is equal to $6.6720 \pm 0.0041 \times 10^{-8} \mathrm{~cm}^{3} / \mathrm{g} \mathrm{s}^{2}$ (Taylor and Cohen, 1973 ) and $1 / 4 \pi \mathrm{k}$ is equal to $39.131 \pm 0.024$ in units of $\mathrm{g} / \mathrm{cm}^{3}$, milligals, and feet.

$\mathrm{F}$ is the normal free-air vertical gradient of gravity that for the Geodetic Reference System of 1967 is given with sufficient accuracy by the equation

$$
\mathrm{F}=0.094114-0.000134 \sin ^{2} \phi-0.0000000134 \mathrm{~h}
$$

where $\phi$ is latitude and $\mathrm{h}$ is elevation in feet, $\mathrm{F}$ varies from $0.093990 \mathrm{mgal} / \mathrm{ft}$ at the well-head gravity station to $0.094058 \mathrm{mgal} / \mathrm{ft}$ at the deepest gravity station. Using an average value of $0.094024 \mathrm{mgal} / \mathrm{ft}$ for $\mathrm{F}$, the above equation becomes

$$
\bar{\rho}=3.679-39.131(\Delta \mathrm{g} / \Delta \mathrm{z})
$$

Interval density between any two borehole gravity stations a and $\mathrm{b}$ may be calculated from

$$
\bar{\rho}=3.679-39.131\left(\mathrm{~g}_{\mathrm{b}}-\mathrm{g}_{\mathrm{a}}\right) / \Sigma \Delta \mathrm{z} \quad \mathrm{g}_{\mathrm{b}}>\mathrm{g}_{\mathrm{a}}
$$

where $\mathrm{g}_{\mathrm{a}}$ and $\mathrm{g}_{\mathrm{b}}$ are relative gravity at $\mathrm{a}$ and $\mathrm{b}$ and $\Sigma \Delta \mathrm{z}$ is the sum of the $\Delta \mathrm{z}$ values between a and $\mathrm{b}$.

Standard deviation of interval density expressed in $\mathrm{g} / \mathrm{cm}^{3}$ is the square root of the sum of the squares of the frictional standard deviations of $\Delta \mathrm{g}$ and $\Delta \mathrm{z}$ multiplied by interval density. For example, standard deviation of the sixth interval density is

$$
\sqrt{(0.0119)^{2}+(0.0019)^{2}}(2.575)=0.031 \mathrm{~g} / \mathrm{cm}^{3}
$$

COLUMNS $15 \& 16$

Interval grain densities were estimated from lithologic descriptions that were obtained primarily from cuttin $\approx s$, cores, and well logs from the Gebo Unit No. 28 and adjacent wells and secondarily from Mills (1956), Maughan (1972) and other sources as referenced. Estimates of interval grain density are least accurate in those parts of the section were rocks of contrasting mineral densities occur together in uncertain proportions ( for example, carbonates or evaporites with shales and sandstones, chert in carbonates, or coal with sandstones and shales). 
Interval porosity was calculated with the equation

$$
\bar{\phi}=100\left(\bar{\rho}-\bar{\rho}_{\mathrm{g}}\right) /\left(\bar{\rho}_{\mathrm{f}}-\bar{\rho}_{\mathrm{g}}\right)
$$

where $\bar{\rho}=$ interval density (column 13)

$\bar{\rho}_{\mathrm{g}}=$ interval grain density (column 14 )

$\bar{\rho}_{\mathrm{f}}=1.00 \mathrm{~g} / \mathrm{cm}^{3}$ (assumed interval pore fluid density)

Errors in interval density $(\bar{\rho})$ and estimated grain density $\left(\bar{\rho}_{\mathrm{g}}\right)$ introduce errors in calculated interval porosity. For example, erroneously high estimates of grain density result in erroneously high calculated values of porosity and vice versa. On the other hand, erroneously high values of interval density result in erroneously low calculated values of porosity and vice versa. Fractional standard deviations of interval density (column 14) and estimated uncertairty in grain density (column 16), the latter treated as a standard deviation, were used to calculate standard deviation in interval porosity. The fractional standard deviation of the numerator of the porosity equation is equal to the square root of the sum of the squares of the fractional standard deviations of $\bar{\rho}$ and $\bar{\rho}_{\mathbf{g}}$ divided by $\left(\bar{\rho}-\bar{\rho}_{\mathbf{g}}\right)$. The fractional standard deviation of the denominator of the porosity equation is equal to the uncertainty in $\bar{\rho}_{\mathbf{g}}$ divided by $\bar{\rho}_{\mathbf{g}}$. Then the standard deviation in interval porosity, expressed in porosity percent, is the square root of the sum of the squares of the fractional standard deviations of the numerator and denominator multiplied by the interval porosity. For example, standard deviation for the sixty-seventh interval porosity is

$$
\left\{\left[\frac{\sqrt{(.040)^{2}+(0.01)^{2}}}{2.407-2.66}\right]^{2}+\left[\frac{(.01)}{2.66}\right]^{2}\right\}^{1 / 2} \quad(15.2)=2.5 \text { porosity percent }
$$

A third source of possible error in interval porosity involves the assumed value of $1.00 \mathrm{~g} / \mathrm{cm}^{3}$ for pore fluid density. If significant amounts of hydrocarbons are present in a given interval, the actual average pore fluid density may be substantially less than $1.00 \mathrm{~g} / \mathrm{cm}^{3}$. In such cases, use of $1.00 \mathrm{~g} / \mathrm{cm}^{3}$ for pore fluid density results in erroneously hiwh calculated values of interval porosity. For particular intervals where pore fluid density is believed to be significantly different from $1.00 \mathrm{~g} / \mathrm{cm}^{3}$ the following equation may be used to determine the correction to interval porosity:

$$
\Delta \phi=\Delta \bar{\rho}_{\mathrm{f}} /\left(1-\bar{\rho}_{\mathrm{g}}-\Delta \bar{\rho}_{\mathrm{f}}\right)(\bar{\phi})
$$

where $\bar{\phi}$ is the calculated interval porosity expressed in percent (column 17), $\Delta \bar{\rho}_{\mathrm{f}}$ is 1.00 minus true pore fluid density and $\Delta \phi$ is the error in calculated porosity expressed in porosity percent. Errors in interval porosity due to the use of 1.00 $\mathrm{g} / \mathrm{cm}^{3}$ for pore fluid density are believed to be small for the Tensleep reservoir at Gebo. For example, the interval porosity of 15.2 percent for interval 67 would be 14.6 percent if, because of the presence of hydrocarbons, the actual pore fluid density were $0.93 \mathrm{~g} / \mathrm{cm}^{3}$ instead of the assumed value of $1.00 \mathrm{~g} / \mathrm{cm}^{3}$.

\section{COLUMN 19}

Sequential numbers for 74 intervals. 
SUPPLEMENT: Explanation and Tabulation of Data From Borehole Gravity Survey of Gebo Unit No. 28

COLUMN 1

Sequential numbers for 75 borehole gravity stations.

COLUMNS $2,3 \& 4$

Gravity station elevations and borehole depths were calculated from cable length measurements and the references given below. The calibration of the cable measuring sheave is believed to be accurate to 0.03 percent or better, based on many tests with the well-conditioned logging cable. Elevation and depth data were not corrected for borehole deviation from the vertical.

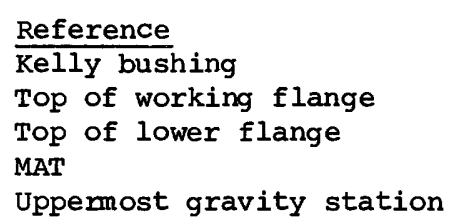

* Depth datum for well logs.

* Depth datum for borehole gravity survey.

\begin{tabular}{c} 
Elevation in feet \\
\hline $4,473 *$ \\
$4,462.9 * *$ \\
$4,461.9$ \\
4,461 \\
$4,457.1$
\end{tabular}

COLUMN 5

Terrain corrections were calculated by the method described by Beyer and Corbato (1972) for topography that extends 103.6 miles outward from the well. The density of the topography was assumed to be $2.50 \mathrm{~g} / \mathrm{cm}^{3}$.

\section{COLUMNS $6 \& 7$}

Values of borehole gravity adjusted to an assumed zero value for the uppermost gravity station. These values are corrected for gravimeter calibration, predicted tidal gravity fluctuatjons, terrain effects, and gravimeter drift as reconstructed from repeated measurements made at a wellhead base station and eight downhole stations.

Uncertainty in relative gravity is the sum of the uncertainties associated with (1) repeatability of individual gravimeter readings, (2) evaluation of gravimeter drift corrections, and (3) calculation of terrain corrections. In a practical sense, uncertainty as used here can be thought of as the maximum likely variation of a gravity value relative to the values of gravity at the two adjacent borehole gravity stations located above and below the staticn of consideration.

\section{COLUMNS $8 \& 9$}

$\Delta g$ is obtained by forming the difference between successive pairs of values of relative gravity. Uncertainty in $\Delta g$ is the sum of the uncertainties of the relative gravity values used to determine $\Delta \mathrm{g}$. 
Distances between adjacent stations $(\Delta z)$ were detemined in one of two ways. values of $\Delta z$ less than 50 feet were measured by hand-chaining flagged cable lengths under load between the winch and wellhead. Hand-chained $\Delta z$ values are repeatable to the nearest 0.02 feet and are underlined in the tabulation. Values of $\Delta z$ greater than 50 feet were determined from suscessive odometer readings of the cable measuring sheave and are repeatable to about 0.15 feet, based on many comparisons with hand-chained cable lengths. It was assumed that cable movement at the ground surface accurately reflected movement of the logging tool in the borehole.

\section{COLUMN 12}

Gravity difference $(\Delta g)$ divided by depth difference $(\Delta z)$ is the interval vertical gradient of gravity.

COLUMNS $13 \& 14$

Interval density $(\bar{\rho})$ was calculated with the equation:

$$
\bar{\rho}=(1 / 4 \pi k)(F-\Delta g / \Delta z)
$$

where $k$ is the Newtonian gravitational constant and is equal to $6.6720 \pm 0.0041 \times 10^{-8} \mathrm{~cm} / \mathrm{g}^{3}$ $\mathrm{sec}^{2}$ (Taylor and Cohen, 1973) and $1 / 4 \pi \mathrm{k}$ is equal to $39.131 \pm 0.024$ in units of $\mathrm{g} / \mathrm{cm}^{3}, \mathrm{milligals}$, and feet.

$F$ is the normal free-air vertical gradient of gravity that for the Geodetic Reference system of 1967 is given with sufficient accuracy by the equation

$$
F=0.094114-0.000134 \sin ^{2} \phi-0.0000000134 h
$$

where $\phi$ is latitude and $h$ is elevation in feet. F varies from $0.093990 \mathrm{mgal} / \mathrm{ft}$ at the wellhead gravity station to $0.094058 \mathrm{mgal} / \mathrm{ft}$ at the deepest gravity station. Using an averare value of $0.094024 \mathrm{mgal} / \mathrm{ft}$ for $\mathrm{F}$, the interval density equation becomes

$$
\bar{\rho}=3.679-39.131(\Delta g / \Delta z)
$$

Interval density between any two borehole gravity stations a and b may be calculated frcm

$$
\bar{\rho}=3.679-39.131\left(g_{b}-g_{a}\right) / \Sigma \Delta z \quad g_{b}>g_{a}
$$

where $g_{a}$ and $g_{b}$ are relative gravity $a t a$ and $b$ and $\Sigma \Delta z$ is the sum of the $\Delta z$ values between $a$ and $b$. A simple measure of the uncertainty in interval density expressed in $\mathrm{g} / \mathrm{cm}^{3}$ is the difference between interval densities calculated with and without the uncertainties in $\Delta g$ and $\Delta z$.

$$
\bar{\rho}_{\text {error }}=39.131\left|\frac{\Delta g-\Delta g \text { error }}{\Delta z+\Delta z \text { error }}-\frac{\Delta g}{\Delta z}\right| g / \mathrm{cm}^{3}
$$

For example, the uncertainty in the sixth interval density is

$$
39.131\left|\frac{0.304-0.005}{10.78+0.02}-0.02820\right|=0.020 \mathrm{~g} / \mathrm{cm}^{3}
$$


Interval grain densities were estimated from lithologic descriptions that were obtained primarily from cuttings, cores and well logs from the Gebo Unit No. 28 and adjacent wells and secordarily from Mills (1956), Maughan (1972) and other sources as referenced. Estimates of interva] grain density are least accurate in those parts of the section where rocks of contrasting mineral densities occur together in uncertain proportions (for example, carbonate and/or evaporito with shale and sandstone, chert in carbonate, or coal with sandstone and shale).

COLUMNS $17 \& 18$

Interval porosity was calculated with the equation

$$
\bar{\phi}=100\left(\bar{\rho}-\bar{\rho}_{g}\right) /\left(\bar{\rho}_{f}-\bar{\rho}_{g}\right)
$$

where $\bar{\rho}=$ interval density (column 13)

$\bar{\rho}_{g}=$ interval grain density (column 15)

$\bar{\rho}_{\mathrm{f}}=1.00 \mathrm{~g} / \mathrm{cm}^{3}$ (assumed interval pore fluid density)

Uncertainties in interval density and estimated grain density introduce uncertainties in calculated interval porosity. For example, erroneously high estimates of grain density result in erroneously high calculated values of porosity and vice versa. on the other hand, erroneously high values of interval density result in erroneously low calculated values of porosity and vice versa. Generally, the largest deviation in calculated porosity occurs when the uncertainty in interval density ( $\bar{\rho}$ error) is added to $\bar{\rho}$ and the uncertainty in grain density ( $\left.\bar{\rho}_{\mathrm{gerror}}\right)$ is subtracted from $\bar{\rho}_{\mathrm{g}}$ in the porosity equation. Following this procedure, a simple measure of the uncertainty in interval porosity is the difference between porosities calculated with and without $\bar{\rho}_{\text {error }}$ and $\bar{\rho}_{\text {gerror }}$.

$$
\bar{\phi}_{\text {error }}=100\left|\frac{\left(\bar{\rho}+\bar{\rho}_{\text {error }}\right)-\left(\bar{\rho}_{g}-\bar{\rho}_{\text {gerror }}\right)}{\bar{\rho}_{f}-\left(\bar{\rho}_{g}-\bar{\rho}_{\text {gerror }}\right)}-\phi\right| \text { porosity percent }
$$

For example, the uncertainty in the sixty-seventh interval porosity is

$$
100\left|\frac{(2.407+0.032)-(2.66-0.01)}{1.00-(2.66-0.01)}-0.152\right|=2.5 \text { porosity percent }
$$

A third source of possible error in interval porosity involves the assumed value of $1.00 \mathrm{~g} / \mathrm{cm}^{3}$ for pore fluid density. If significant amounts of hydrocarbons are present in a given interval, the actual average pore fluid density may be substantially less than $1.00 \mathrm{~g} / \mathrm{cm}^{3}$. In such $\mathrm{cases,}$ use of $1.00 \mathrm{~g} / \mathrm{cm}^{3}$ for pore fluid density results in erroneously high calculated values of interval porosity. For particular intervals where pore fluid density is believed to be significantly different from $1.00 \mathrm{~g} / \mathrm{cm}^{3}$, the following equation may be used to determine the correction to interval porosity:

$$
\Delta \phi=\left[\left(\Delta \bar{\rho}_{f} /\left(1-\bar{\rho}_{g}-\Delta \bar{\rho}_{f}\right)\right](\bar{\phi})\right.
$$

$\bar{\phi}$ is the calculated interval porosity expressed in percent (column 17$), \Delta \bar{\rho}_{f}$ is 1.00 minus true pore fluid density, and $\Delta \phi$ is the error in calculated porosity expressed in porosity percent. Errors in interval porosity due to the use of $1.00 \mathrm{~g} / \mathrm{cm}^{3}$ for pore fluid density are believed to be small for the Tensleep reservoir at Gebo. For example, the interval porosity of 15.2 percent for interval 67 would be 14.6 percent if, because of the presence of hydrocarbons, the actual pore fluid density were $0.93 \mathrm{~g} / \mathrm{cm}^{3}$ instead of the assumed value of $1.00 \mathrm{~g} / \mathrm{cm}^{3}$. 


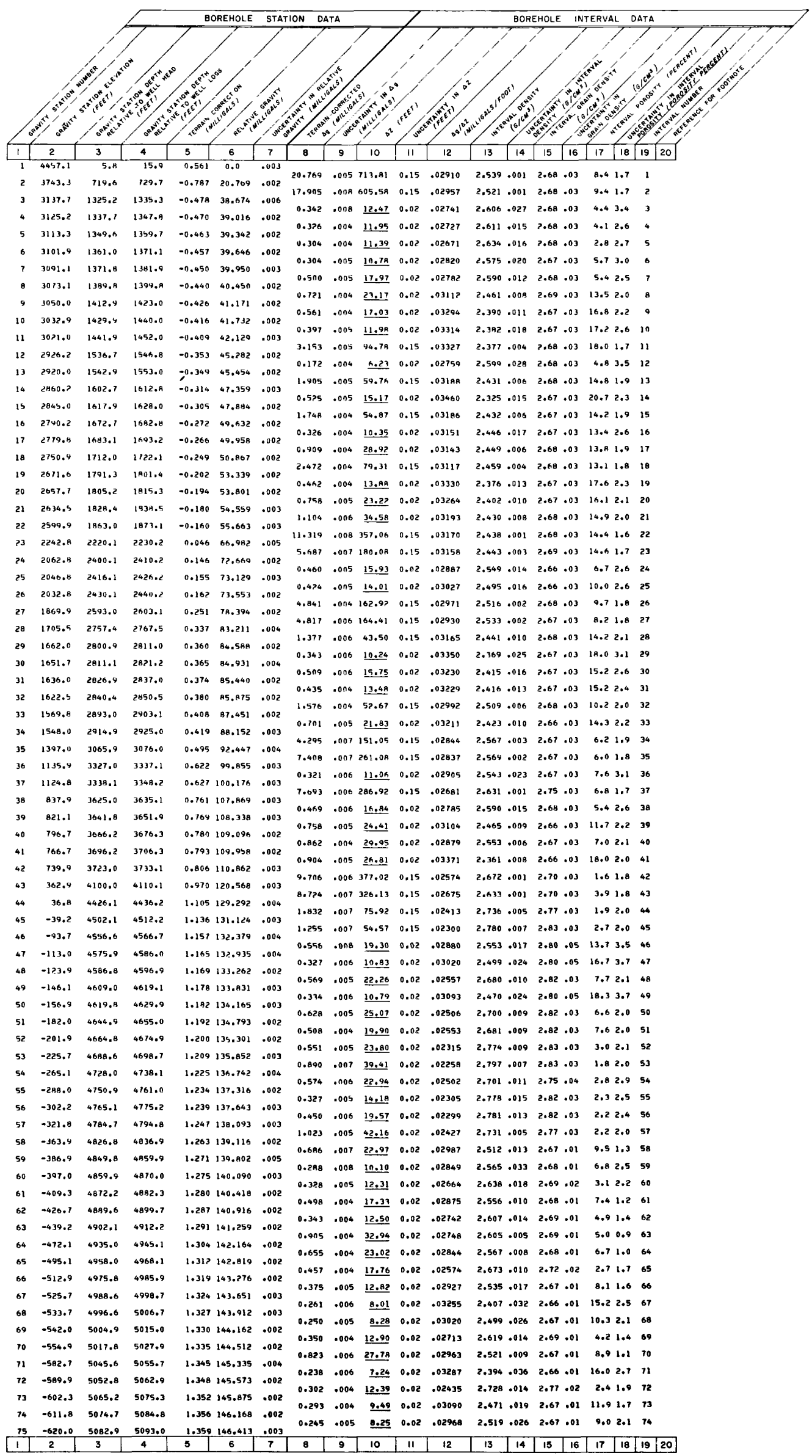

